Article

\title{
Effect of Aluminum Oxide on the Performance of Ionic Liquid-Based Aluminum-Air Battery
}

\author{
Christopher Welch ${ }^{1}$, Abdul Kaleem Mohammad ${ }^{1}$, Narayan S. Hosmane ${ }^{2}$, Lu Zhang ${ }^{3}$ and \\ Kyu Taek Cho ${ }^{1, *(D)}$ \\ 1 Electrochemical Thermal Energy Laboratory, Department of Mechanical Engineering, Northern Illinois \\ University, Dekalb, IL 60115, USA; chriswelch774@gmail.com (C.W.); makaleem1993@gmail.com (A.K.M.) \\ 2 Department of Chemistry and Biochemistry, Northern Illinois University, Dekalb, IL 60115, USA; \\ hosmane@niu.edu \\ 3 Chemical Sciences and Engineering Division, Argonne National Laboratory, Lemont, IL 60439, USA; \\ luzhang@anl.gov \\ * Correspondence: kcho@niu.edu; Tel.: +1-815-753-3346
}

Received: 11 March 2020; Accepted: 7 April 2020; Published: 17 April 2020

\begin{abstract}
The aluminum-air (or oxygen) battery has received intense attention in the past because of its excellent benefits such as low cost and high energy density, but due to the challenging issues such as hydrogen evolution and inactive oxide film formation on the Al surface, it could not be fully applied. In this study, 1-Ethyl 3-Methyl Imidazolium Chloride ([EmIm]Cl) and aluminum chloride $\left(\mathrm{AlCl}_{3}\right)$ are applied to resolve the aforementioned issues. Ex situ component-level and in situ cell-level open circuit voltage (OCV) tests combined with the physics-based model analyses were conducted to investigate the electrochemical reaction behaviors of the Al-air cell. Especially, the effect of aluminum oxide formation on the anode- and cathode-side reactions were analyzed in detail. The oxide film formed at the Al surface strongly was found to significantly impede the electrochemical reaction at the surface, and the film growth was controlled by decreasing the surface tension by aggressive anions. In the cathode side, the aluminum oxide precipitated in the porous cathode electrode was found to decrease the porous reaction area and block reactant access into the reaction sites. The effects of $\mathrm{O}_{2}$ solubility in the electrolyte, initial porosity and thickness of the porous electrode are compared in detailed, and optimal thickness is suggested.
\end{abstract}

Keywords: aluminum air battery; aluminum electrode; ionic liquid; oxide film; surface tension; oxide precipitation; porous electrode; volume average

\section{Introduction}

The demand for batteries to store and release electrical energy keeps increasing as electronic devices become widespread and fossil-based systems are replaced by electricity-based systems. Lithium-ion batteries have been considered one of the most promising power sources for mobile and transportation systems, but face the challenging issues of high cost, low capacity (i.e., short operation hours or driving ranges), and safety concerns. Therefore, it is necessary to find breakthrough technologies to resolve these issues.

In this research, we focus on characterizing aluminum as a promising anode material that is expected to bring new direction of research and development to overcome the challenging issues of the conventional battery system. Aluminum is cheap and abundant, benign to the environment, and stable in moisture. Moreover, it has the excellent volume charge-storage capacity of $8.0 \mathrm{Ah} / \mathrm{cm}^{3}$ (or $3.0 \mathrm{Ah} / \mathrm{g}$ ), which is approximately four times greater than that of lithium (i.e., $2.06 \mathrm{Ah} / \mathrm{cm}^{3}$ or $3.9 \mathrm{Ah} / \mathrm{g}$ ), leading to its energy contents comparable to those of gasoline (i.e., specific energy density: $8.1 \mathrm{kWh} / \mathrm{kg}$ for Al-air 
and $13 \mathrm{kWh} / \mathrm{kg}$ for gasoline, and volumetric energy density: $21.8 \mathrm{kWh} / \mathrm{L}$ for $\mathrm{Al}$-air and $9.7 \mathrm{kWh} / \mathrm{L}$ for gasoline) [1-5]. However, even with these promising features, an Al-based rechargeable battery could not reach the commercialization stage due to the problems of self-corrosion and aluminum oxide film formation during cell operation [6]. Especially, due to the reduction potential of aluminum ion $(-1.68 \mathrm{~V}$ vs. Standard Hydrogen Electrode (SHE)) which is lower than hydrogen reduction from water, the charge (or aluminum deposition) is not possible thermodynamically in aqueous systems [1-6].

As a promising electrolyte to resolve these issues, an ionic liquid which is molten salt in liquid form at room temperature is getting intense attention recently owing to the excellent benefits of no $\mathrm{H}_{2}$-generating side reactions and stability in the reduction potential of $\mathrm{Al}$ ion, which allows the cell to be charged. The first research to apply ionic liquid to an aluminum-air battery system was reported by D. Gelman et al. [4]. They utilized 1-Ethyl, 3-Methyl Imidazolium oligo-fluoro hydrogenate (EmIm-(HF) $\left.)_{2,3}-\mathrm{F}\right)$ because of its high conductivity $(100 \mathrm{mS} / \mathrm{cm})$, low viscosity, and chemical stability with oxygen and water. It was reported that $\mathrm{Al}$ was stable in the ionic liquid with a negligible corrosion rate, leading to a current density of $1.5 \mathrm{~mA} / \mathrm{cm}^{2}$ and a capacity of $140 \mathrm{mAh} / \mathrm{cm}^{2}$.

R. Revel et al. [7] reported the performance of an Al-air battery including relatively inexpensive and commercially available 1-Ethyl, 3-Methyl Imidazolium chloride $([\mathrm{EmIm}] \mathrm{Cl})$ and aluminum chloride $\left(\mathrm{AlCl}_{3}\right)$. They controlled the acidity of ionic liquid by changing the ratio of $[\mathrm{EmIm}] \mathrm{Cl}$ and $\mathrm{AlCl}_{3}$, and its effects on the conductivity of the ionic liquid and the corrosion rate of $\mathrm{Al}$ metal were investigated. Cell performances of $0.6 \mathrm{~mA} / \mathrm{cm}^{2}$ and average voltage of 0.6 to $0.8 \mathrm{~V}$ were reported, and the charge behavior was reported for the first time in an Al-air battery. Especially, the capacity was reported to be $71 \mathrm{mAh} / \mathrm{cm}^{2}$, equal to that of an Li-air battery and five to ten times superior than that of an Li-ion battery, suggesting that the Al-air battery is highly promising to outperform other existing metal-air batteries.

However, the promising ionic liquid-based Al-air battery faces challenging issues, and one of them is the formation of an inactive oxide layer on the Al surface which blocks electrochemical reactions at the Al surface. B. Shvartsev et al. and D. Gelman et al. reported that the inert oxide film could not be easily dissolved in the conventional ionic liquid solution, and various ionic liquids (i.e., $\mathrm{EmIm}(\mathrm{HF})_{2,3}$-F, 1-Ethyl-3-methylimidazolium tri-fluoro-methanesulfonate (EmImOTF), and 1-Ethyl-3-Methylimidazolium bis-(tri-fluoro-methyl-sulfonyl) amide (EmImTFSI)) were utilized to investigate their effect on morphology change of the oxide film through electrochemical methods (i.e., two-electrode and three-electrode cells) and surface analysis (Transmission Electron Microscope (TEM), Energy Dispersive X-ray Spectroscopy (EDS), X-ray Photoelectron Spectroscopy (XPS), and Atomic force microscopy (AFM)). It was found that a new film was formed instead of the pristine oxide layer due to interaction between $\mathrm{Al}$ and the ionic liquid, transforming the passive state to the active behavior of the metal. Feng Wu et al. [8] recently reported also that poor cycling performance is due to an interface problem between the anode and electrolyte, and by immersing $\mathrm{Al}$ into the electrolyte as a pretreatment method, the passive film could be removed. They also found that a stable SEI (solid-electrolyte interphase) layer on the anode surface was formed, which was beneficial for improving interface stability, demonstrating the interface-reconstruction effect by the way of an efficient facile pretreatment of the Al metal anode.

Issues on the cathode air side were also reported, and D. Gelman et al. [9] found that adverse effect of $\mathrm{Al}_{2} \mathrm{O}_{3}$ precipitation on the cathode electrode was a critical issue in the cell performance. The $\mathrm{Al}_{2} \mathrm{O}_{3}$ is generated in the cathode side during discharge operation, but it is precipitated on the electrode surface once its solubility limit in the ionic liquid is exceeded, decreasing the porosity of the electrode, which impedes the reactant transport in the porous structure and covers the available active sites for the oxygen reduction reaction. They concluded that battery capacity is limited by the air electrode, and it is important to study and develop a robust air cathode, capable of extending the battery life.

However, to the best of our knowledge, there is no prior research which analyzed these challenging issues in both the anode and cathode sides of the ionic liquid-based Al-air (or $\mathrm{O}_{2}$ ) cell through mathematical modeling to define key controlling parameters to resolve those issues. It is necessary to 
understand the physics underlying the electrochemical reactions at electrode interfaces, including the formation/ breakdown mechanism of the inert oxide film formed on the $\mathrm{Al}$ electrode surface, and the effect of precipitation of $\mathrm{Al}_{2} \mathrm{O}_{3}$ on the cathode surface in the porous electrode, in order to define key parameters controlling the performance of the Al-air battery. In this study, systematic research which combines experimentation and mathematical modeling was conducted to elucidate the multiphysical cell behavior.

The cell-based experiment was conducted with ionic liquid electrolytes with various ratios of [EmIm]Cl to $\mathrm{AlCl}_{3}$, and the effect of the ratio (i.e., acidity) on the cell performance and the morphology of $\mathrm{Al}$ surface was measured with OCV and SEM images. In particular, thermodynamics relations were utilized to understand the acidity effect on Al-surface morphology. In addition, a one-dimensional micro-macro homogeneous mathematical model, which incorporates the properties of Al-surface morphology in the anode and the physics associated with $\mathrm{Al}_{2} \mathrm{O}_{3}$ precipitation in the cathode porous electrode, was developed to predict the cell performance and define the key control parameters which provide guidance for cell developers.

\section{Experimental}

An ionic liquid employing [EmIm] Cl (97\%, Acros Organics) and $\mathrm{AlCl}_{3}$ (99\%, Sigma-Aldrich) was used as the electrolyte. Both the chemicals were stored in an argon glove box as they are very hygroscopic and sensitive to moisture. [EmIm] Cl was heated at $130{ }^{\circ} \mathrm{C}$ under vacuum for $18-20 \mathrm{~h}$ to remove the residual water [7]. $\mathrm{AlCl}_{3}$ was then added to the melt in an argon atmosphere and stirred at room temperature until a clear, transparent liquid was formed. The ionic liquid was made in various ratios of $[\mathrm{EmIm}] \mathrm{Cl}$ and $\mathrm{AlCl}_{3}$ from 1:0.5 to 1:2. A 3/8 inch Swagelok cell made of Teflon was used to measure the open circuit voltage (OCV) of the cell. A 99.999\% aluminum sheet (Alfa-Aesar) was used as the anode electrode, and a platinum-coated carbon porous layer prepared as described in [10] was used as the cathode electrode. Whatman $囚 34-\mathrm{AH}$ filter paper served as a membrane, and stainless steel rods and pipes (McMaster Carr) were used as current collectors for the anode and cathode sides, respectively. The different ratio affects the conductivity of the ionic liquid, which was determined using a conductivity meter (PC-100, Cole-Palmer). A scanning electron microscope (Vega II SBH, TESCAN) was used to perform an SEM analysis to study the effect of the electrolyte on the oxide film on the aluminum surface. An SP-150 Biologic instrument was used to study the OCV behavior of the battery. To study the effect of chloride ions on the oxide film, aluminum samples were submerged in ionic liquid electrolytes with varied ratios of $[\mathrm{EmIm}] \mathrm{Cl}$ to $\mathrm{AlCl}_{3}$ for varied times, and the $\mathrm{OCV}$ and surface morphology were measured through a cell test and SEM.

\section{Modeling}

A diagram of the $\mathrm{Al}$-air cell is shown in Figure 1. From left to right, the cell contains an aluminum metal anode, an $\mathrm{Al}_{2} \mathrm{O}_{3}$ film on the surface of the anode, a porous separator, and a porous carbon air cathode; all components except for the anode have their cracks and pores completely filled with 1:1.5 $[\mathrm{EmIm}] \mathrm{Cl}-\mathrm{AlCl}_{3}$ concentrated electrolyte. 


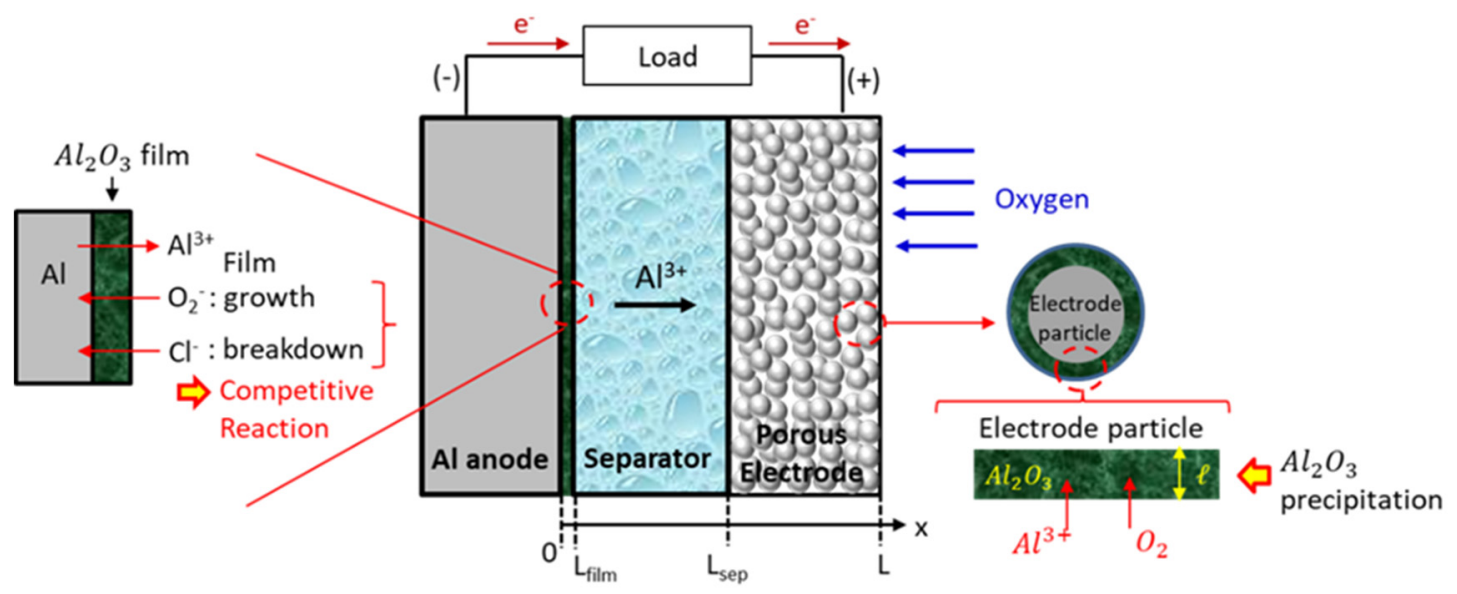

Figure 1. Diagram of Al-air battery discharge.

During discharge operation, the $\mathrm{Al}$ metal is dissolved in the $[\mathrm{EmIm}] \mathrm{Cl}-\mathrm{AlCl}_{3}$ electrolyte, as described by Equation (1), which is the primary electrochemical reaction at the anode. The $\mathrm{Al}_{2} \mathrm{O}_{3}$ layer on the anode contains cracks that allow limited $\mathrm{Al}^{3+}$ diffusion and electrolyte conductance. The layer greatly reduces the surface area available for $\mathrm{Al}$ dissolution, causing the film to have impedance and hence contributes to a potential drop between the solid anode and electrolyte at the film surface. The $\mathrm{Al}^{3+}$ diffuses through the separator and into the porous carbon cathode. Atmospheric $\mathrm{O}_{2}$ dissolves in the electrolyte and diffuses into the cathode at the side of the current collector and reacts with $\mathrm{Al}^{3+}$ to form $\mathrm{Al}_{2} \mathrm{O}_{3}$, as in Equation (2), which is the primary cathodic electrochemical reaction. The $\mathrm{Al}_{2} \mathrm{O}_{3}$ produced is dissolved in the electrolyte before reaching a solubility limit after which it precipitates on the cathode's carbon particle surfaces. The two electrochemical reaction equations for the electrodes are combined to form the full electrochemical reaction (Equation (3)) [7].

$$
\begin{gathered}
\text { Anode side : } A l \rightleftharpoons A l^{3+}+3 e^{-} \quad \mathrm{E}_{\mathrm{a}}^{0}=-1.66 \mathrm{~V} \\
\text { Cathode side : } A l^{3+}+\frac{3}{4} \mathrm{O}_{2}+3 e^{-} \rightleftharpoons \frac{1}{2} \mathrm{Al}_{2} \mathrm{O}_{3} \quad \mathrm{E}^{0} \mathrm{c}=1.05 \mathrm{~V} \\
\text { Overall reaction : } A l+\frac{3}{4} \mathrm{O}_{2} \rightleftharpoons \frac{1}{2} \mathrm{Al}_{2} \mathrm{O}_{3} \quad \mathrm{E}_{\text {cell }}^{0}=2.71 \mathrm{~V}
\end{gathered}
$$

Equation (1) is the net reaction of the reaction: $\mathrm{Al}+7 \mathrm{AlCl}_{4}^{-} \rightleftharpoons 4 \mathrm{Al}_{2} \mathrm{Cl}_{7}^{-}+3 \mathrm{e}^{-}$[11]. Simulations will be conducted on the model developed in this study to predict the discharge performance, which will be verified by experimental data. The effects of important parameters such as anodic film crack density, solubility of oxygen in the electrolyte, and the initial porosity and thickness of the cathode on the cell performance will be analyzed in detail.

\subsection{Assumptions for Model}

$\mathrm{Al}_{2} \mathrm{O}_{3}$ is the primary product of the cell reaction [4].

Species in the electrolyte have even initial distributions across the cell geometry.

Pore spaces of the electrode and separator are assumed to be filled with electrolyte.

Pure dry $\mathrm{O}_{2}$ is provided externally into the porous cathode at the current collector.

There is no $\mathrm{Al}_{2} \mathrm{O}_{3}$ in the cathode at the beginning of discharge.

Concentrated solution theory is used to consider ionic liquid-based electrolyte in the simulation.

There are no effects of convection.

Isothermal conditions at $300 \mathrm{~K}$. 


\subsection{Volume Average Method}

The porous electrode was utilized in the cathode side to increase the interfacial reaction area between the electrode and the electrolyte, resulting in the complicated microscopic and interfacial phenomena for the analysis. And thus, it is required to utilize the simpler macroscale models that capture the dominant physics in the microscale, and the macroscale models can be derived by averaging the microscopic equations over a representative elementary volume that contains all phases. The general averaging theorems [12-14] are described for temporal derivatives,

$$
\left\langle\frac{\partial \Psi_{k}}{\partial t}\right\rangle=\frac{\partial\left\langle\Psi_{k}\right\rangle}{\partial t}-\frac{1}{V_{0}} \int_{A_{k}} \Psi_{k} \mathbf{w}_{\mathrm{k}} \cdot \mathbf{n}_{\mathrm{k}} d A
$$

and for spatial derivatives,

$$
\left\langle\nabla \Psi_{k}\right\rangle=\nabla\left\langle\Psi_{k}\right\rangle+\frac{1}{V_{0}} \int_{A_{k}} \Psi_{k} \mathbf{n}_{k} d A
$$

where $\Psi_{k}$ is any quantity in phase $\mathrm{k}, V_{0}$ is the volume of representative elementary volume, $\mathbf{w}_{\mathrm{k}}$ is the velocity of the surface-bounding phase $\mathrm{k}, \mathbf{n}_{\mathrm{k}}$ is the normal unit vector pointing outward from phase $\mathrm{k}$, and $A_{k}$ is the total interfacial area of the k-phase adjacent to all other phases.

The averaging operators are for phase volume averages [12-14]:

$$
\left\langle\Psi_{k}\right\rangle=\frac{1}{V_{0}} \int_{V_{0}} X_{k} \Psi_{k} d V
$$

and for intrinsic volume averages:

$$
\left\langle\Psi_{k}\right\rangle^{k}=\frac{1}{V_{k}} \int_{V_{0}} X_{k} \Psi_{k} d V
$$

where $X_{k}$ denotes a phase function, equal to one in phase $\mathrm{k}$ and zero elsewhere, and $V_{k}$ is the volume of phase $\mathrm{k}$ in $V_{0}$. The two averages are related by

$$
\left\langle\Psi_{k}\right\rangle=\frac{V_{k}}{V_{0}} \frac{1}{V_{k}} \int_{V_{0}} X_{k} \Psi_{k} d V=\varepsilon_{k}\left\langle\Psi_{k}\right\rangle^{k}
$$

These volume average methods were applied to convert microscopic equations to macroscopic continuum equations, and details can be found in the Appendix A.

\subsection{Application of the General Macroscopic Equations to Al-Air System}

Equation (A20) can be simplified for conditions of single electrochemical reaction $j$ and no convection effect of the electrolyte:

$$
\frac{\partial\left\langle\varepsilon_{k}\left\langle c_{k}\right\rangle^{k}\right\rangle}{\partial t}=\nabla \cdot\left(D_{k}^{e f f} \nabla\left\langle c_{k}\right\rangle^{k}\right)-a_{k m} \frac{t_{k}}{z F} \bar{i}_{n j}-a_{k m} \frac{s_{j}}{n_{j} F}
$$

where the first and second terms in the right-hand side of the equation can be replaced by divergence of ionic flux with Equations (A8) and (A11), and the third term is defined by the reaction rate of the species (i.e., source term).

$$
\begin{gathered}
\nabla \cdot\left(D_{k}^{e f f} \nabla\left\langle c_{k}\right\rangle^{k}\right)-a_{k m} \frac{t_{k}}{z F} \bar{i}_{n j}=\nabla \cdot\left(D_{k}^{e f f} \nabla\left\langle c_{k}\right\rangle^{k}\right)-\frac{t_{k}}{z F} \frac{1}{V_{0}} \int_{A_{k m}} \mathbf{i}_{k} \cdot \mathbf{n}_{k} d A=-\nabla \cdot\left\langle\mathbf{N}_{\mathbf{k}}\right\rangle \\
r_{j}=-a_{k m} \frac{s_{j}}{n_{j} F} \bar{i}_{n j}
\end{gathered}
$$


The final useful form of the macroscopic species conservation equation is obtained for the reactive species in the electrolyte (i.e., $\mathrm{k}$ phase is now electrolyte, and the average symbols were dropped out for convenience):

$$
\frac{\partial\left(\varepsilon c_{j}\right)}{\partial t}=-\nabla \cdot \mathbf{N}_{j}+r_{j}
$$

where $\varepsilon$ is the liquid phase volume fraction (porosity), $c$ is the species molar concentration, and $\mathbf{N}$ and $r$ are the mole flux and reaction rate of a species $j$.

Because there are no convection effects, the molar flux, which is the rate of movement of a species over a cross section, is determined only by diffusion and migration for the $\mathrm{AlCl}_{3}$ salt, and diffusion only for the oxygen. The molar flux rates of $\mathrm{Al}^{3+}, \mathrm{Cl}^{-}$, and $\mathrm{O}_{2}$ are expressed as:

$$
\begin{gathered}
\mathbf{N}_{A l^{3+}}=-D_{A l C l_{3}, e f f} \nabla c_{A l C l_{3}}+\frac{\mathbf{i}_{\mathrm{e}} t_{+}}{3 F} \\
\mathbf{N}_{C l^{-}}=-3 D_{A l C l_{3}, e f f} \nabla c_{A l C l_{3}}-\frac{\mathbf{i}_{\mathrm{e}}\left(1-t_{+}\right)}{F} \\
\mathbf{N}_{\mathrm{O}_{2}}=-D_{\mathrm{O}_{2}, e f f} \nabla c_{\mathrm{O}_{2}}
\end{gathered}
$$

where $D^{e f f}$ is the effective diffusivity, $\mathbf{i}_{\mathrm{e}}$ is liquid phase current density, and $t_{+}$is the cation transference number.

The relation of solid phase current can be described from Equations (A21) and (A20):

$$
\nabla \cdot \varepsilon_{s}\left\langle\mathbf{i}_{s}\right\rangle^{s}=\nabla \cdot\left(\sigma^{e f f} \nabla\left\langle\varphi_{s}\right\rangle^{s}\right)
$$

And thus, the solid phase current is:

$$
\mathbf{i}_{s}=\sigma^{e f f} \nabla \varphi_{s}
$$

where $\varepsilon_{S}$ is one, $\sigma^{e f f}$ is the effective electric conductivity in the solid material, and $\varphi_{S}$ is the potential in the solid phase.

For the liquid phase, the current relation is obtained from Equations (A22) and (A20):

$$
\nabla \cdot \varepsilon_{e}\left\langle\mathbf{i}_{e}\right\rangle^{e}=-\nabla \cdot\left(k^{e f f} \nabla\left\langle\varphi_{e}\right\rangle^{e}\right)-\nabla \cdot\left(k_{D}^{e f f} \nabla \ln \left\langle c_{e}^{i}\right\rangle^{e}\right)
$$

For the cation species in the electrolyte,

$$
\mathbf{i}_{e}=-k^{e f f} \nabla \varphi_{e}-k^{e f f} \frac{v R T}{F}\left(\frac{s_{+}}{n v_{+}}+\frac{t_{+}^{0}}{z_{+} v_{+}}-\frac{s_{0} c_{e}}{n c_{0}}\right)\left(1+\frac{d \ln f_{ \pm}}{d \ln c_{e}}\right) \nabla \ln c_{e}
$$

where $\varepsilon_{e}$ is one, $k^{e f f}$ is the effective electrolyte ionic conductivity, $\varphi_{e}$ is the liquid potential. In the Al-air model, $v=4, z_{+}=3, v_{+}=1, n=3, s_{0}=0$, and $s_{+}=-1$.

Due to porosity and increased path length, or tortuosity, the Bruggeman relationship [15] with an exponent of 1.5 is used to determine conductivity and diffusivity affected by porosity and tortuosity in the porous media:

$$
\begin{aligned}
D_{\mathrm{AlCl}_{3}}^{e f f} & =\varepsilon^{1.5} D_{\mathrm{AlCl}_{3}} \\
D_{\mathrm{O}_{2}}^{\text {eff }} & =\varepsilon^{1.5} D_{\mathrm{O}_{2}} \\
k^{e f f} & =\varepsilon^{1.5} \kappa \\
\sigma^{e f f} & =\varepsilon_{s}^{1.5} \sigma
\end{aligned}
$$


where $\varepsilon_{S}$ is the solid electrode volume fraction, $\varepsilon$ is the electrolyte volume fraction or porosity, and $D, k$, and $\sigma$ are the standard diffusivity, liquid phase conductivity, and solid phase conductivity without obstacles.

Between the solid and liquid phase, there must be conservation of charge. Therefore, from Equations (A23) and (A20),

$$
\left.a_{s e} \sum_{j} \bar{i}_{n j}\right|_{s}+\left.a_{s e} \sum_{j} \bar{i}_{n j}\right|_{e}=0 \rightarrow \nabla \cdot \mathbf{i}_{\mathrm{s}}+\nabla \cdot \mathbf{i}_{\mathrm{e}}=0
$$

The electrochemical reaction on the electrode surface involves electrons and reactive species, which can be described as:

$$
\sum s_{j} M_{j}^{Z_{j}} \rightarrow n e^{-}
$$

where $s, M$, and $z$ are the stoichiometric coefficient, species symbol, and charge of a species. It tells that the reaction rate at the electrode surface must be proportional to the transfer current.

The charge transfer (i.e., superficial current density, $\mathbf{i}_{\mathbf{e}}$ ) from solid to electrolyte phase per unit volume of electrode is related to the product of specific area (i.e., interface area per unit volume of electrode, $a$ ) and the average interfacial current density $\left(\bar{i}_{n}\right)$ (for convenience, the overbar will be taken off in the relations hereafter). For a single reaction at the interface, from Equation (A20):

$$
\nabla \cdot \mathbf{i}_{\mathbf{e}}=a \bar{i}_{n}
$$

\subsection{Equations for the Anode Side}

The electrochemical reaction rate (aluminum dissolution) at the anode surface is described by the Butler-Volmer equation:

$$
i_{a, n}=\varepsilon_{\text {crack }} i_{0}\left[\exp \left(\frac{\beta_{a} n F \eta_{a}}{R T}\right)-\exp \left(\frac{-\left(1-\beta_{a}\right) n F \eta_{a}}{R T}\right)\right]
$$

where $i_{0}$ is the exchange current density, $\beta_{a}$ is the charge transfer coefficient for the oxidation in the anode-side reaction, $\varepsilon_{\text {crack }}$ is the fraction of the electrode surface which is exposed (i.e., crack density) due to the cracks of the oxide film covering the Al electrode surface, and $\eta_{a}$ is the surface overpotential, defined as follows:

$$
\eta_{a}=\varphi_{s}^{a}-\varphi_{e}^{a}-E_{a}
$$

where $\varphi_{s}^{a}$ and $\varphi_{e}^{a}$ are the potentials of the solid electrode and liquid electrolyte at the interface in the anode side, and $E_{a}$ is the anode equilibrium potential.

It is assumed that the electrochemical reaction takes place only within the exposed area of the anode (i.e., area under the cracked portion of the film). The crack is formed through competitive reactions between the film formation by the reaction of aluminum and water or oxygen dissolved in the ionic liquid and the film-breaking reaction of the aggressive chloride ions in the electrolyte. This reaction is assumed to occur immediately, and the formed crack fraction (i.e., crack density) is maintained during cell operation. The crack density was measured directly from the morphology of the aluminum surface in SEM by using ImageJ2 free software [16].

The solid oxide material is considered inert and only the electrolyte filling the cracks is conductive, and the ohmic potential drop of the electrolyte through cracks of the film can be calculated by:

$$
\Delta \varphi_{o h m, f}=\frac{i_{a} A l_{f i l m, a}}{\kappa_{f i l m}^{e f f}}
$$


where A is the cross-sectional area of aluminum, $l_{f i l m, a}$ is the oxide film thickness on the anode surface, and $\kappa_{f i l m}^{e f f}$ is the effective ionic conductivity of the electrolyte in the cracks, which is obtained from the Bruggeman relationship (Equation (22)).

\subsection{Equations for the Cathode Side}

The electrochemical reaction at the cathode surface is affected significantly by the concentration of reactive species at the reaction sites and the oxide film formed on the surfaces of electrode particles, which effects are considered by the modified Butler-Volmer equation:

$$
i_{c}=n F\left[C_{R} \exp \left(\frac{\beta_{c} n F \eta_{c}}{R T}\right)-C_{O} \exp \left(\frac{-\left(1-\beta_{c}\right) n F \eta_{c}}{R T}\right)\right]
$$

where $\eta_{c}$ is the kinetic or surface overpotential at the cathode surface and $\beta_{c}$ is the charge transfer coefficients for the oxidation in the cathode-side reaction. The concentration of reactive species for anodic $\left(C_{R}\right)$ and cathodic $\left(C_{O}\right)$ reactions can be described:

$$
\begin{gathered}
C_{R}=k_{a}\left(c_{\mathrm{Al}_{2} \mathrm{O}_{3}}\right) \\
C_{O}=k_{c}\left(c_{A l^{3+}, s}\right)^{2}\left(c_{\mathrm{O}_{2}, s}\right)^{3 / 2}
\end{gathered}
$$

where $k_{a}$ and $k_{c}$ are the anodic and cathodic reaction rate constants.

These species expressions are dependent on the concentrations of the reactants at the surface of the carbon electrode/electrolyte interface. When these concentrations are depleted, the species expression becomes zero and the transfer current is cut off (locally in the cathode). The surface concentrations result from the diffusion of species through the deposited $\mathrm{Al}_{2} \mathrm{O}_{3}$ film layer on the cathode surface. By conservation of species, the diffusion rate through the film must be proportional to the transfer current, which can be expressed as:

$$
\frac{i_{c}}{n F}=\frac{D_{i, f i l m}\left(c_{i}-c_{i, s}\right)}{l_{\text {film }}}
$$

where $l_{\text {film }}$ is the thickness of the $\mathrm{Al}_{2} \mathrm{O}_{3}$ deposition on the cathode surface.

The surface overpotential at the cathode is modified to implement the effect of the existence of the oxide film covering the electrode:

$$
\eta_{c}=\varphi_{s}^{c}-\varphi_{e}^{c}-\Delta \varphi_{f i l m}-E_{c}
$$

where $\Delta \varphi_{\text {film }}$ is the potential drop across the oxide film and $E_{c}$ is the cathode equilibrium potential.

There is no information in the literature about crack density of $\mathrm{Al}_{2} \mathrm{O}_{3}$ deposited on the carbon electrode, and thus the approach in [16] was utilized in this study to implement the effect of $\mathrm{Al}_{2} \mathrm{O}_{3}$ deposition.

The oxide (i.e., $\mathrm{Al}_{2} \mathrm{O}_{3}$ ) generated in the cathode side has a solubility limit in the electrolyte. When this limit is surpassed, the oxide precipitates on the carbon electrode surface. The concentration of the solid deposit of $\mathrm{Al}_{2} \mathrm{O}_{3}$ increases over discharge at a rate proportional to the transfer current in the cathode:

$$
\frac{\partial c_{s_{1}, \mathrm{Al}_{2} \mathrm{O}_{3}}}{\partial t}=\left(\frac{a \mathrm{Al}_{2} \mathrm{O}_{3}}{n_{e} \mathrm{~F}} \bar{i}\right) \times\left(c_{\mathrm{Al}_{2} \mathrm{O}_{3}} \geq c_{\max , \mathrm{Al}_{2} \mathrm{O}_{3}}\right)
$$

where $s_{A l 2 O 3}$ is the stoichiometric coefficient for $\mathrm{Al}_{2} \mathrm{O}_{3}$ and $c_{\max , \mathrm{Al}_{2} \mathrm{O}_{3}}$ is the solubility limit of $\mathrm{Al}_{2} \mathrm{O}_{3}$ in the electrolyte.

The oxide film covers the carbon cathode surface and decreases the specific area of the electrode. The amount of loss of active surface depends on the morphology of the deposit on the carbon particles, as shown in Equation (36) [14,17]: 


$$
a=a_{0}\left[1-\left(\frac{\varepsilon_{A l_{2} O_{3}}}{\varepsilon_{s}^{0}}\right)^{q}\right]
$$

where $a_{0}$ is the initial specific interface area without any oxide film and $q$ is a geometric factor for the morphology of the oxide on the surface of the carbon cathode; small values of $q$ indicate a flat, plate-like precipitate, and large values reflect a needle-like solid. The value of 0.5 is used in this model. As the $\mathrm{Al}_{2} \mathrm{O}_{3}$ continues to precipitate on the carbon cathode, it fills in space previously occupied by the electrolyte, reducing the porosity of the cathode. The change rate of porosity is determined by the size of the $\mathrm{Al}_{2} \mathrm{O}_{3}$ particles and the rate of production.

The film potential drop in the cathode is due to electrical resistance for ion transport through the film and adds to the total potential drop between the solid phase and liquid phase. It increases over discharge as more $\mathrm{Al}_{2} \mathrm{O}_{3}$ is deposited in the porous cathode, leading to increased effective impedance. The film potential drop [18] is expressed as:

$$
\Delta \varphi_{\text {film }}=i_{c} R_{\text {film,ref }} \varepsilon_{\mathrm{Al}_{2} \mathrm{O}_{3}}
$$

where $R_{\text {film,ref }}$ is the resistance of oxide film and $\varepsilon_{\mathrm{Al}_{2} \mathrm{O}_{3}}$ is the volume fraction of the cathode occupied by the oxide film.

As the oxide volume fraction increases during discharge, the porosity of the electrode decreases. The total volume fractions of the electrolyte, solid $\mathrm{Al}_{2} \mathrm{O}_{3}$, and carbon electrode in the cathode equal one and is expressed as:

$$
\varepsilon_{\mathrm{Al}_{2} \mathrm{O}_{3}}=1-\varepsilon-\varepsilon_{s}^{0}
$$

The porosity variation in the porous electrode can be calculated with the macroscopic mass conservation equation (Equation (A2)). The interface movement is caused by species transformation during the electrochemical reaction, and thus the average normal velocity $\left(\bar{w}_{n, k m}\right)$ of the $\mathrm{k}-\mathrm{m}$ interface in Equation (A2) for a single reaction in the cathode can be described as [14]:

$$
\bar{w}_{n, k m}=a_{k m} \rho_{k} \sum_{j}\left(\frac{s_{j}}{n_{j} F} \bar{i}_{n j} \bar{V}_{s}\right)=a_{k m} \rho_{k} \frac{s_{j}}{n_{j} F} \bar{i}_{n j} \bar{V}_{s}
$$

where $\bar{V}_{S}$ is partial molar volume of species in the solid phase.

Therefore, the porosity variation in the porous electrode can be defined from Equation (A2) and $\bar{V}_{s}=M_{\mathrm{Al}_{2} \mathrm{O}_{3}} / \rho_{\mathrm{Al}_{2} \mathrm{O}_{3}}$ :

$$
\frac{\partial \varepsilon}{\partial t}=-a \frac{\bar{i}}{2 F} \frac{M_{A l_{2} O_{3}}}{\rho_{A l_{2} O_{3}}}
$$

where $\mathrm{M}_{\mathrm{Al}_{2} \mathrm{O}_{3}}$ and $\rho_{\mathrm{Al}_{2} \mathrm{O}_{3}}$ are the molecular weight and density of the oxide deposit.

Locally on the carbon particles' surfaces, the deposition of $\mathrm{Al}_{2} \mathrm{O}_{3}$ forms an oxide layer covering the surface. During discharge, this layer will increase in thickness according to the amount of $\mathrm{Al}_{2} \mathrm{O}_{3}$ deposited and the shape of the carbon particle. In other words, this thickness is determined by the volume fractions of the carbon and solid $\mathrm{Al}_{2} \mathrm{O}_{3}$ that can be shown for a spherical particle as:

$$
l_{\text {film }}=r_{0}\left[\left(\frac{\varepsilon_{s}^{0}+\varepsilon_{A l_{2} O_{3}}}{\varepsilon_{s}^{0}}\right)^{\frac{1}{3}}-1\right]
$$

where $r_{0}$ is the radius of the carbon particle. 


\subsection{Initial and Boundary Conditions}

\subsubsection{Initial conditions}

Initial conditions for all the species concentration inside the cell, structure of cathode porous electrode (i.e. porosity, thickness, and specific interfacial area) were summarized in Table 1. It was assumed that species in the electrolyte have even initial distributions across the cell geometry, pore spaces of the electrode and separator are filled with electrolyte, and there is no $\mathrm{Al}_{2} \mathrm{O}_{3}$ in the cathode at the beginning of discharge.

Table 1. Parameters used in the model.

\begin{tabular}{|c|c|c|c|c|}
\hline Parameter Description & Symbol & Value & Units & Ref. \\
\hline Cross-section area of the cell & A & 1 & $\mathrm{~m}^{2}$ & - \\
\hline Initial active specific surface area of the cathode & $a_{0}$ & 262.54 & $\mathrm{~m}^{2} / \mathrm{m}^{3}$ & Calculated \\
\hline Initial concentration of $\mathrm{AlCl}_{3}$ in the electrolyte & $\mathrm{c}_{\mathrm{AlCl}_{3,0}}$ & 500 & $\mathrm{~mol} / \mathrm{m}^{3}$ & {$[19,20]$} \\
\hline Solubility limit of $\mathrm{Al}_{2} \mathrm{O}_{3}$ in the electrolyte & $\mathrm{C}_{\max , \mathrm{Al}_{2} \mathrm{O}_{3}}$ & 0.09 & $\mathrm{~mol} / \mathrm{m}^{3}$ & {$[21]$} \\
\hline Atmospheric concentration of $\mathrm{O}_{2}$ & $\mathrm{C}_{2}, \mathrm{~atm}$ & 9.46 & $\mathrm{~mol} / \mathrm{m}^{3}$ & [22] \\
\hline Diffusivity of $\mathrm{AlCl}_{3}$ in the electrolyte & $\mathrm{D}_{\mathrm{AlCl}_{3, \text { ref }}}$ & $2.1 \times 10^{-9}$ & $\mathrm{~m}^{2} / \mathrm{s}$ & [23] \\
\hline Diffusivity of $\mathrm{O}_{2}$ in the electrolyte & $\mathrm{D}_{\mathrm{O}_{2, \text { ref }}}$ & $7 \times 10^{-10}$ & $\mathrm{~m}^{2} / \mathrm{s}$ & [24] \\
\hline Activity dependence & $\mathrm{dlnf} / \mathrm{dln} \mathrm{c}$ & -1.03 & - & [25] \\
\hline Anodic reaction rate at the cathode & $\mathrm{k}_{\mathrm{a}}$ & $1.1 \times 10^{-15}$ & $\mathrm{~m} / \mathrm{s}$ & [18] \\
\hline Cathodic reaction rate at the cathode & $\mathrm{k}_{\mathrm{c}}$ & $3.4 \times 10^{-17}$ & $\mathrm{~m}^{7.5} \mathrm{~mol}^{-2.5} \mathrm{~s}^{-1}$ & [18] \\
\hline Reaction rate at the $\mathrm{Al}$ anode & $\mathrm{k}_{\mathrm{Al}}$ & $1.5 \times 10^{-9}$ & $\mathrm{~m} / \mathrm{s}$ & (a) Assumed \\
\hline Thickness of the oxide film on the anode & $\mathrm{L}_{\text {film,a }}$ & $5 \times 10^{-6}$ & $\mathrm{~m}$ & Measured \\
\hline Thickness of the porous carbon cathode & $\mathrm{L}_{\mathrm{C}}$ & $2.5 \times 10^{-5}-1.6 \times 10^{-3}$ & $\mathrm{~m}$ & Assumed \\
\hline Thickness of the separator & $\mathrm{L}_{\mathrm{S}}$ & $5 \times 10^{-5}$ & $\mathrm{~m}$ & [26] \\
\hline Molecular weight of $\mathrm{Al}^{3+}$ & $\mathrm{M}_{\mathrm{Al}^{3+}}$ & 0.027 & $\mathrm{~kg} / \mathrm{mol}$ & [27] \\
\hline Molecular weight of $\mathrm{Cl}^{-}$ & $\mathrm{M}_{\mathrm{Cl}^{-}}$ & 0.045 & $\mathrm{~kg} / \mathrm{mol}$ & [27] \\
\hline Molecular weight of [EmIm]Cl & $\mathrm{M}_{[\mathrm{EmIm}] \mathrm{Cl}}$ & 0.147 & $\mathrm{~kg} / \mathrm{mol}$ & [7] \\
\hline Molecular weight of $\mathrm{Al}_{2} \mathrm{O}_{3}$ & $\mathrm{M}_{\mathrm{Al}_{2} \mathrm{O}_{3}}$ & 0.102 & $\mathrm{~kg} / \mathrm{mol}$ & [27] \\
\hline Electrons transferred in the anode reaction & $\mathrm{n}_{\mathrm{a}}$ & 3 & mole of $\mathrm{e}^{-}$ & [19] \\
\hline Electrons transferred in the cathode reaction & $\mathrm{n}_{\mathrm{c}}$ & 6 & mole of $\mathrm{e}^{-}$ & {$[7]$} \\
\hline Interfacial oxide film resistance in the cathode & $R_{\text {film,ref }}$ & 50 & $\Omega \mathrm{m}^{2}$ & [28] \\
\hline Radius of a particle in the porous cathode & $\mathrm{r}_{0}$ & $2.5 \times 10^{-8}$ & $\mathrm{~m}$ & [29] \\
\hline Solubility factor of $\mathrm{O}_{2}$ into the porous cathode & $\mathrm{S}_{\mathrm{O}_{2}}$ & $0.2-0.8$ & - & Assumed \\
\hline [EmIm] Cl stoichiometric coefficient in reaction & $\mathrm{s}^{0}$ & 0 & - & - \\
\hline Cation stoichiometric coefficient in reaction & $s^{+}$ & -1 & - & - \\
\hline Temperature at which the cell operates & $\mathrm{T}$ & 300 & $\mathrm{~K}$ & Assumed \\
\hline Transference number of $\mathrm{Al}^{3+}$ & $\mathrm{t}^{+}$ & 0.963 & - & (a) Assumed \\
\hline Anion charge number & $\mathrm{z}^{-}$ & -1 & - & - \\
\hline Cation charge number & $\mathrm{z}^{+}$ & 3 & - & - \\
\hline Oxidation charge transfer coefficient at anode & $\beta_{a}$ & 0.246 & - & [19] \\
\hline Oxidation charge transfer coefficient at cathode & $\beta_{c}$ & 0.5 & - & (a) Assumed \\
\hline Initial porosity in the porous carbon cathode & $\varepsilon_{0}$ & 0.73 & - & [30] \\
\hline Initial carbon cathode volume fraction & $\varepsilon_{s}^{0}$ & 0.27 & - & Calculated \\
\hline Porosity in the separator & $\varepsilon_{\text {sep }}$ & $0.2-0.94$ & - & Assumed \\
\hline Ratio of exposed surface area at the anode & $\varepsilon_{\text {crack }}$ & 0.2 & - & Measured \\
\hline Electrolyte ionic conductivity & $\mathrm{K}_{\mathrm{AlCl}}{ }_{3, \text { ref }}$ & 1.4 & $\mathrm{~S} / \mathrm{m}$ & [7] \\
\hline $\begin{array}{l}\text { Total number of moles of ions per mole of } \\
\text { electrolyte }\end{array}$ & 2. $13, \mathrm{ret}$ & 4 & - & - \\
\hline Number of moles of $\mathrm{Cl}$ - per mole of electrolyte & $v^{-}$ & 3 & - & - \\
\hline Number of moles of $\mathrm{Al}^{3+}$ per mole of electrolyte & $v^{+}$ & 1 & - & - \\
\hline Density of carbon cathode material & $\rho_{\mathrm{c}}$ & 2260 & $\mathrm{~kg} / \mathrm{m}^{3}$ & [31] \\
\hline Density of $\mathrm{Al}_{2} \mathrm{O}_{3}$ deposit & $\rho_{\mathrm{Al}_{2} \mathrm{O}_{3}}$ & 3987 & $\mathrm{~kg} / \mathrm{m}^{3}$ & [27] \\
\hline Density of electrolyte solution & $\rho_{\mathrm{e}}$ & 1351.7 & $\mathrm{~kg} / \mathrm{m}^{3}$ & [20] \\
\hline Conductivity of carbon cathode & $\sigma_{\mathrm{c}}$ & 10 & $\mathrm{~S} / \mathrm{m}$ & [22] \\
\hline
\end{tabular}

(a) Assumed by matching the simulation to the experimental data with limited information in literature [32].

\subsubsection{Boundary Conditions}

Boundary conditions are based upon the schematic shown in Figure 1. At the cathode current collector (i.e. $\mathrm{x}=\mathrm{L}$ ), the oxygen gas of constant concentration is provided into the cell externally, and the solid-phase current density is equal to the applied current density, but electrolyte current density is zero, and fluxes of species at this interface are zero. At the interfaces of cathode electrode/separator and separator/anode electrode, the solid-phase current density is zero, but the liquid-phase current density is equal to the applied current density, and species concentrations and fluxes are continuous. 
At the interface of $\mathrm{x}=0$, the flux is equal to the consuming/production rate of $\mathrm{Al}$ ions due to the electrochemical reaction occurring at the solid/liquid interface. The potential of the solid phase at $x=0$ is set to zero, and the solid phase potential at $\mathrm{x}=\mathrm{L}$ is set to the cell voltage.

The equations and boundary conditions were applied in the equation-based solver COMSOL multiphysics version 5.3. Simulations of the Al-air battery were performed on a 64 bit Windows computer with an Intel i7 $3.20 \mathrm{GHz}$ processor and 16 GB RAM. A time dependent solver was used for the equations and a variable tolerance of 0.001 was used.

\section{Results and Discussion of Experiment and Modeling}

\subsection{Effect of Chloride ion Concentration}

The effect of $\mathrm{Cl}^{-}$concentration on film breakdown in the anode side was investigated with different $\mathrm{Cl}^{-}$contents in the ionic liquid electrolyte. A piece of pure aluminum metal was submerged in the ionic liquid solution with the 1:0.5 molar ratio of $[\mathrm{EmIm}] \mathrm{Cl}$ to $\mathrm{AlCl}_{3}$ for about 4 hours. Isolated blisters (less than $20 \mu \mathrm{m}$ in size) and minor cracks were formed on the surface of the aluminum (i.e., oxide film), as shown in Figure 2a. The isolated blisters became larger in size and were connected, and cracks were enlarged as the ratio of $[\mathrm{EmIm}] \mathrm{Cl}$ to $\mathrm{AlCl}_{3}$ changed to 1:1. As the ratio increased further to 1:1.5, all the surfaces of $\mathrm{Al}$ were covered with cracks, and severe breakdown of the oxide film was found.

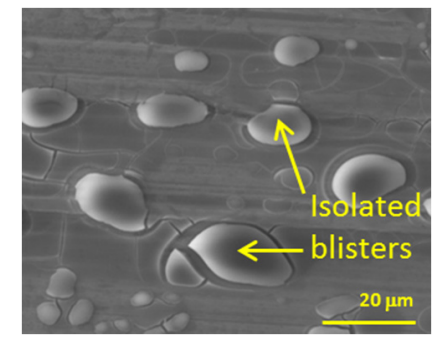

(a)

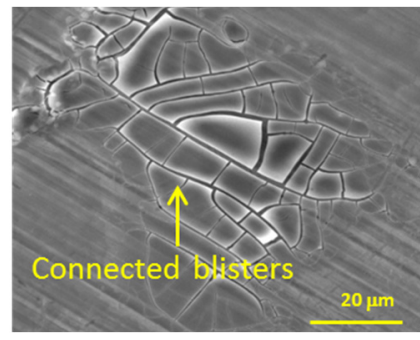

(b)

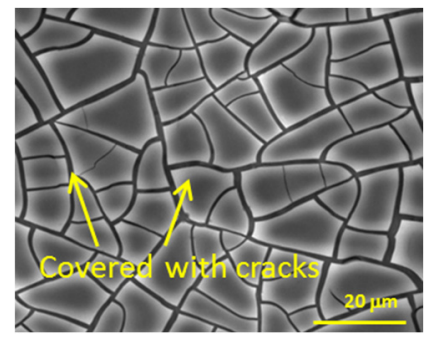

(c)

Figure 2. Effect of ratio of 1-Ethyl 3-Methyl Imidazolium Chloride ([EmIm]Cl) to $\mathrm{AlCl}_{3}$ on the morphology of oxide film: (a) ratio $=1: 0.5,(\mathbf{b})$ ratio $=1: 1$, (c) ratio $=1: 1.5$.

Effect of those morphology changes on the open circuit voltage (OCV) are compared in Figure 3. The OCV was measured to be $0.9 \mathrm{~V}$ in the case of the 1 to 0.5 ratio, and it increased continuously with increasing molar ratio of $\mathrm{AlCl}_{3}$, and reached $1.4 \mathrm{~V}$ for the 1:1.5 ratio. However, it dropped with further increase of $\mathrm{AlCl}_{3}$. This decrease was considered due to the effect of the $\mathrm{Cl}^{-}$ion, which is known to be adsorbed on the oxide film to enhance the breakdown process. As the ratio changed from 1:0.5 to 1:1.5, the more active area of $\mathrm{Al}$ electrode was available for electrochemical reaction due to the increased cracks on inert oxide film formed on the $\mathrm{Al}$ electrode, resulting in an OCV increase. However, the OCV decreased significantly at the ratio of $1: 2$, which may be interpreted as the direct effect of $\mathrm{Cl}^{-}$ion (i.e., corrosion) on the active area of the $\mathrm{Al}$ electrode, and the $\mathrm{Cl}^{-}$ion affected not only the oxide film but also the $\mathrm{Al}$ active area.

It is reported that at the ionic liquid ratio of 1:0.5, the dominant chloro-aluminate species in the electrolyte is $\mathrm{AlCl}_{4}{ }^{-}[7,8,19,33]$. As the ratio of $\mathrm{AlCl}_{3}$ is increased from 1:0.5 to 1:1.5, the ionic liquid contains $\mathrm{AlCl}_{4}{ }^{-}$and $\mathrm{Al}_{2} \mathrm{Cl}_{7}{ }^{-}$species. At 1:0.5 ratio, the conductivity of ionic liquid was only $3.4 \mathrm{mS} / \mathrm{cm}$ due to a lesser amount of salt generating ions. As the $\mathrm{AlCl}_{3}$ ratio increased from 1:0.5 to 1:1, conductivity was increased to $16.2 \mathrm{mS} / \mathrm{cm}$, but then it decreased to $14.6 \mathrm{mS} / \mathrm{cm}$ at the $1: 1.5$ ratio, which may have been affected by the decreased mobility due to the larger size of the $\mathrm{Al}_{2} \mathrm{Cl}_{7}{ }^{-}$ion dominant at that ratio. 


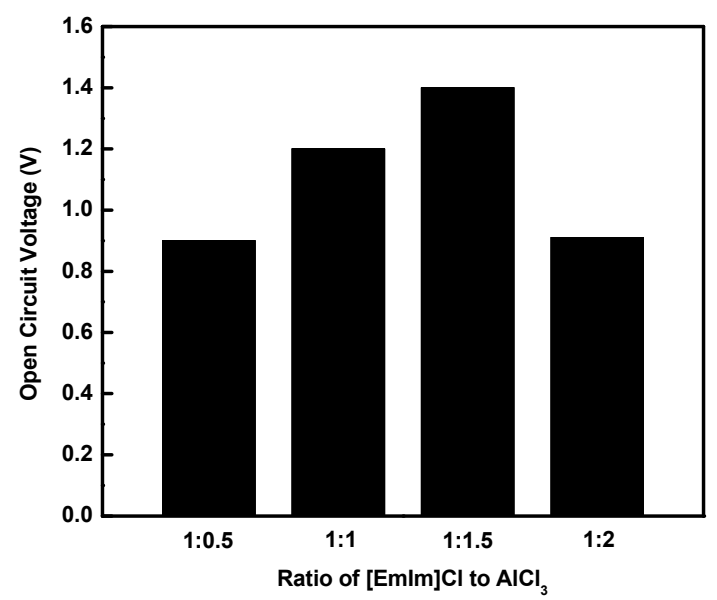

Figure 3. Effect of chloride ion concentration on open circuit voltage (OCV).

\subsection{Theoretical Consideration}

The effect of anion ion (i.e., $\mathrm{Cl}^{-}$) on film breakdown can be understood from the fundamental thermodynamic relations. Studies to understand the mechanism of oxide film formation/breakdown have been conducted in the corrosion area especially for the aqueous system [34-38], and their results can be utilized to understand fundamentals of the film breakdown. The oxide film can be modeled with the concept of double layer of dielectric constant $\varepsilon^{\prime}$ under the electric field $E^{\prime}$ as shown in Figure 4.

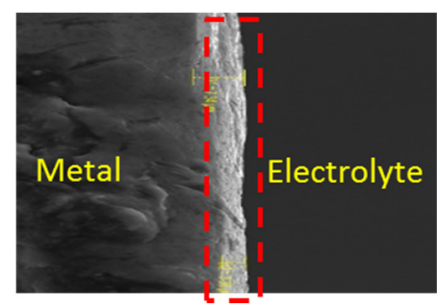

(a)

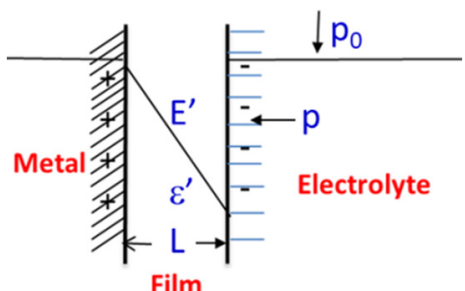

(b)

Figure 4. Interface between electrode surface and electrolyte: (a) SEM and (b) electrical double layer model of oxide film redrawn from [35]. Reproduced with permission from N. Sato, Vol. 16, 1683-1692, Electrochimica Acta; published by Elsevier, October 1971.

Due to the potential difference between the metal surface and the solution, an electric field $E^{\prime}$ acts across the oxide film, generating electrostriction compressive pressure on the film. Whereas, the surface tension $\gamma$ formed on the oxide film stabilizes the film. Thus, net stress exerted on the oxide film can be described by a balance relation between the electrostriction (i.e., force to break the film, the first term in the right-hand side of Equation (42)) and surface tension effects (i.e., force to form and preserve the film, the second term in the right-hand side of the equation) [35]:

$$
p-p_{0}=\frac{\varepsilon_{0}^{\prime} \varepsilon^{\prime}\left(\varepsilon^{\prime}-1\right) E^{\prime 2}}{8 \pi}-\frac{\gamma}{L}
$$

where $p$ is pressure, $\varepsilon_{0} \prime$ is the vacuum permittivity, $8.85 \times 10^{-12}(\mathrm{~F} / \mathrm{m})$ or $\left(\mathrm{C}^{2} / \mathrm{Nm}^{2}\right), \varepsilon^{\prime}$ is the dielectric constant, $E^{\prime}$ is the electric field, $(\mathrm{V} / \mathrm{m})$ or $(\mathrm{N} / \mathrm{C}), \gamma$ is the surface tension, and $L$ is the thickness of the film.

The system of our interest contains anodic oxide film (MO), solution (IL), and salt $\mathrm{AlCl}_{3}$ (i.e., $\mathrm{Al}^{3+}$ and $\mathrm{Cl}^{-}$). From the Gibbs isotherm [39]:

$$
-d \gamma=q d \phi+\Gamma_{A l^{3}} d \mu_{A l}+\Gamma_{C l^{-}} d \mu_{A l C l_{3}}+\Gamma_{A l_{2} \mathrm{O}_{3}} d \mu_{A l_{2} \mathrm{O}_{3}}+\Gamma_{I L} d \mu_{I L}
$$


where $\mathrm{Al}_{2} \mathrm{O}_{3}$ is regarded as an electrically neutral oxide on the Gibbs surface, and $\mu_{\mathrm{Al}}, \mu_{\mathrm{Al}_{2} \mathrm{O}_{2}}, \mu_{\mathrm{IL}}$ are assumed to be constant. Using these assumptions, the relation can be simplified:

$$
-d \gamma \cong q d \phi+\Gamma_{C l^{-}} d \mu_{A l C l_{3}}
$$

This relation clearly shows the surface tension of the film is decreased as the chloride ion content (i.e., $\Gamma_{\mathrm{Cl}^{-}}$) adsorbed on the $\mathrm{Al}$ metal increases, which well explains the experimental results of this study.

The effect of adsorbed ion on the breakdown potential can be understood with works conducted by Sato [35]. Since electric field intensity is generally constant for a film of given thickness, growth or breakdown of the passive film can be controlled by controlling surface tension. The electric field intensity $\mathrm{E}^{\prime}$ in general is on the order of $10^{6} \mathrm{~V} / \mathrm{cm}$, and the thickness of the barrier layer of the oxide film varies from 0.0005 to $0.01 \mu \mathrm{m}$. For aluminum oxides and hydroxides, the dielectric constant is in the range 1-10 and the surface tension is in the range 10-500 dyne/ $\mathrm{cm}$. Metal oxides and hydroxides start to breakdown when the electrostriction pressure is in the range $100-1000 \mathrm{~kg} / \mathrm{cm}$ [35].

The point where electrostriction pressure reaches a breakdown stress of $600 \mathrm{~kg}_{\mathrm{f}} / \mathrm{cm}^{2}$ is considered as the critical thickness of the oxide film [35]. A variation of critical film thickness with electric field intensity is shown in Figure 5a. At an electric field intensity of $4.15 \times 10^{6} \mathrm{~V} / \mathrm{cm}$, the electrostriction pressure developed in the oxide film never exceeds the breakdown stress of $600 \mathrm{~kg}_{\mathrm{f}} / \mathrm{cm}^{2}$. Increasing the electric field intensity to $4.74 \times 10^{6} \mathrm{~V} / \mathrm{cm}$ causes the film to break down at a critical thickness of $0.035 \mu \mathrm{m}$. Critical thickness of the oxide film further decreases to $0.016 \mu \mathrm{m}$ by increasing the electric field intensity to $5.53 \times 10^{6} \mathrm{~V} / \mathrm{cm}$. This high electric field intensity required for the film breakdown causes voltage loss in actual performance of the battery. Therefore, other methods need to be used to reduce voltage loss (i.e., decrease the electric field).

A variation of critical thickness with surface tension is plotted in Figure $5 b$ where the electric field is $4.74 \times 10^{6} \mathrm{~V} / \mathrm{m}$. At a surface tension of $300 \mathrm{dyne} / \mathrm{cm}$, electrostriction pressure developed in the oxide film is less than the breakdown stress of $600 \mathrm{~kg}_{\mathrm{f}} / \mathrm{cm}^{2}$, and the oxide film cannot be broken down at this surface tension. However, as the surface tension decreases from 300 to 100 , and $10 \mathrm{dyne} / \mathrm{cm}$, the critical thickness decreases, indicating the film can be easily broken down at low surface tension without using a large overpotential. Hence, it can be concluded that the surface tension is a key controlling parameter to breakdown the inert oxide film efficiently without causing significant voltage loss in actual battery performance.

\subsection{Overall Discharge Behavior}

The discharge curves predicted from the model developed in this research were compared with full cell performance data of an Al-air battery in ref. [7], as shown in Figure 6. The model, which utilizes the parameters in Table 1 (for all following sections unless specified otherwise), had an OCV of $1.56 \mathrm{~V}$ and the cell discharge time decreased with increasing current density, which agreed with experimental data. However, the initial potential drop in the simulation was immediate and followed directly by a voltage plateau, while in the experimental data, the cell voltage gradually dropped before reaching a voltage plateau. This discrepancy may be due to the simplified cell reactions and assumed kinetic parameter values used in the modeling study because of the lack of information (i.e., parameter data) in the literature, the simplified approach based on Butler-Volmer kinetics, or uncertainties associated with experimental data in the literature. 


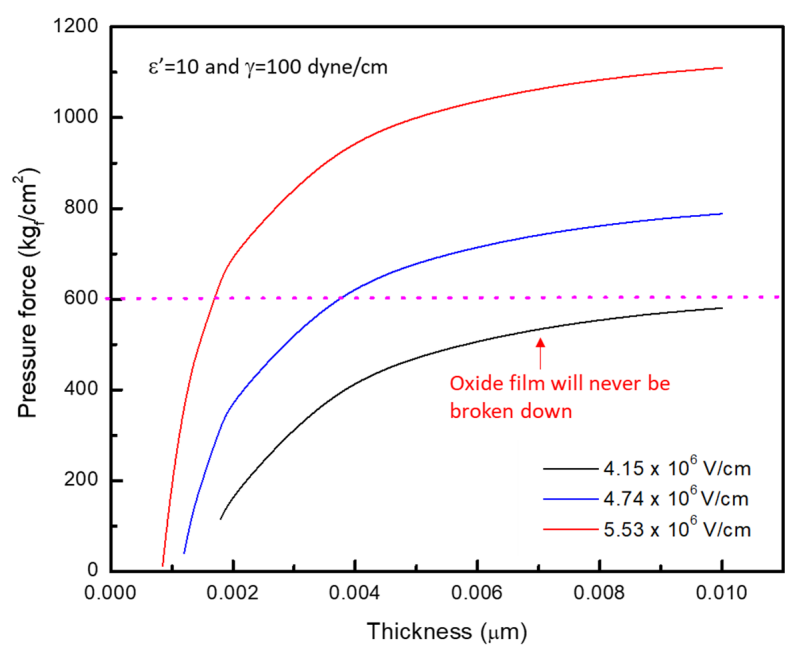

(a) Effect of electric field intensity

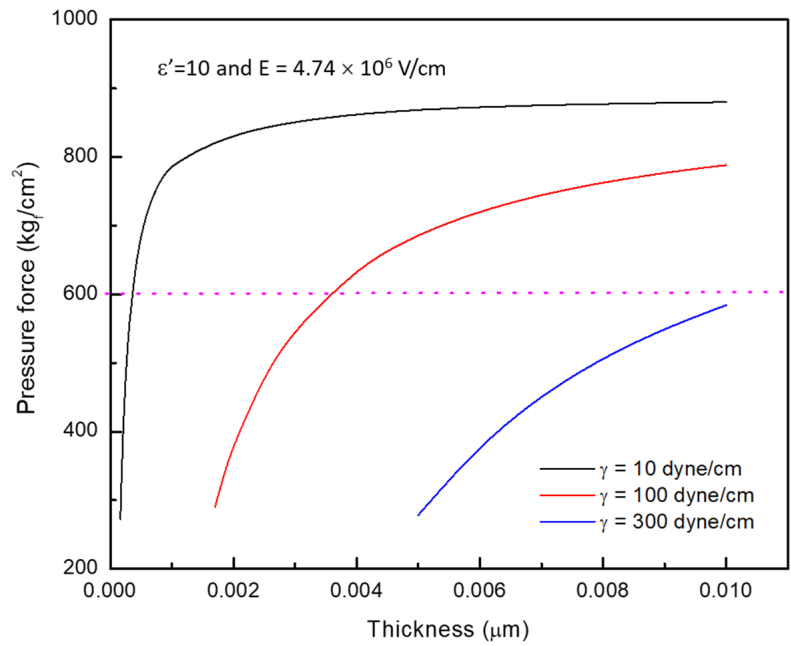

(b) Effect of surface tension

Figure 5. The effect of electric field intensity and surface tension on film breakdown, redrawn from [35]. Reproduced with permission from N. Sato, Vol. 16, 1683-1692, Electrochimica Acta; published by Elsevier, October 1971.

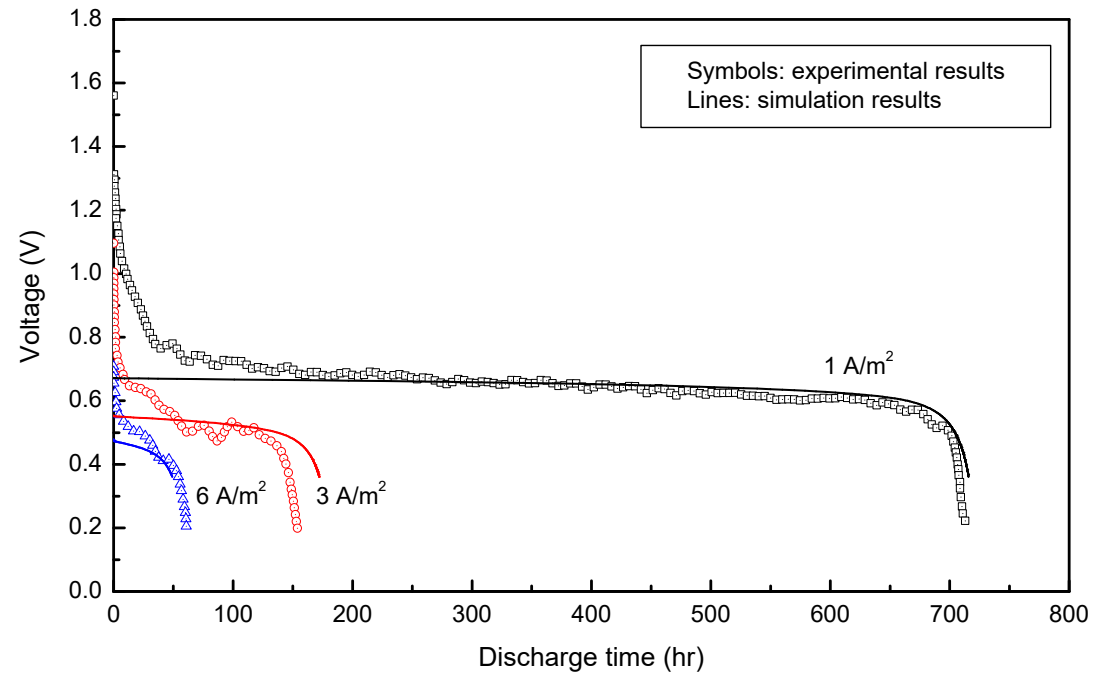

Figure 6. Discharge curves for the Al-air battery for model and experimental data [10]. 
At $1 \mathrm{~A} / \mathrm{m}^{2}$, the simulated voltage reached a plateau at roughly $0.66 \mathrm{~V}$. The cell potential began to rapidly decrease at around $0.6 \mathrm{~V}$ and the cell showed a discharge time of just over 700 hours, which agreed with experimental data. At $3 \mathrm{~A} / \mathrm{m}^{2}$, the experiment and simulation had roughly the same voltage plateau at $0.53 \mathrm{~V}$. However, the discharge for the simulation lasted longer than that in the experiment, and this disagreement may have occurred due to the reasons described previously. At $6 \mathrm{~A} / \mathrm{m}^{2}$, discharge duration was too short to distinguish a plateau voltage for the experiment, however, the discharge time agreed at roughly 60 hours. The model prediction contains a few deviations from the experimental results because of possible reasons described previously, but it described overall discharge behavior successfully. Thus, this model was utilized to analyze characteristic behavior of the ionic liquid-based $\mathrm{Al}$-air cell for which modeling analysis has not been reported.

\subsection{Anode Side: Effect of Oxide Film On Anodic Overpotential}

A major contributor to the cell potential drop (loss) in the anode is the $\mathrm{Al}_{2} \mathrm{O}_{3}$ film layer formed on the $\mathrm{Al}$ surface. The passivation on the anode occurs as a result of deposition of $\mathrm{Al}_{2} \mathrm{O}_{3}$ and is counteracted by dissolution of the $\mathrm{Al}_{2} \mathrm{O}_{3}$ by chloride ions in the electrolyte. The areas under the cracks formed from the partial dissolution of the film exposed to the electrolyte allow $\mathrm{Al}$ to take part in the cell reaction. The effect of the cracks on the anode kinetic performance was investigated with various crack fractions, including $5 \%, 10 \%, 21 \%, 50 \%$, and $100 \%$. In particular, a $100 \%$ crack fraction corresponds to the case where all the films formed on the anode are broken down and no film exists on the Al surface.

As illustrated in Figure 7, the anodic potential loss increased exponentially at a low current range, and then linearly increased as the current increased (i.e. similar to the ohmic loss), which is due to the decreased reaction area caused by the film formation and the restricted transport of ionic species through narrow and tortuous cracks. The significant loss of voltage was found in the case of $5 \%$ crack fraction, and the loss was $1.23 \mathrm{~V}$ at $6 \mathrm{~A} / \mathrm{m}^{2}$, which is $31 \%$ higher than that of the no-oxide film case (i.e., $100 \%$ crack fraction case), and the loss was reduced as the crack fraction increased (i.e., $1.16 \mathrm{~V}$ for $10 \%$ crack fraction, $1.09 \mathrm{~V}$ for $21 \%, 1 \mathrm{~V}$ for $50 \%$, and 0.94 for $100 \%$ at $6 \mathrm{~A} / \mathrm{cm}^{2}$ ). In particular, the $21 \%$ crack fraction is for the case where we found from the ex situ experiment in the electrolyte of 1 to 1.5 molar ratio of $[\mathrm{EmIm}] \mathrm{Cl}$ to $\mathrm{AlCl}_{3}$, and thus the film is expected to increase the anode overpotential by $16 \%$. These results show that removing the oxide film on $\mathrm{Al}$ is important to reduce the anodic potential loss to improve the cell performance. It will be a future direction of research to find proper methods to efficiently remove all of the oxide film, which may be achievable from a fundamental understanding of the mechanism of growth/breakdown of oxide film in the ionic liquid solution.

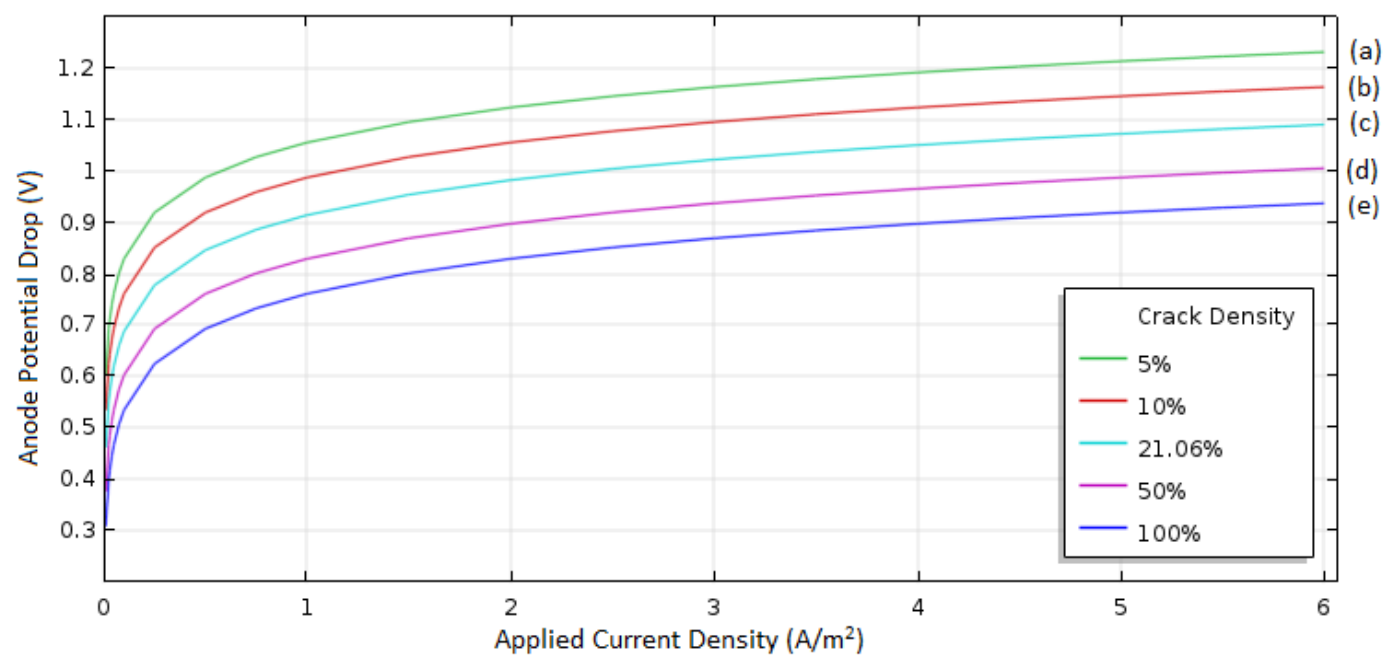

Figure 7. Potential drop between the $\mathrm{Al}$ anode and the anodic oxide film surface at crack fractions of (a) $5 \%$, (b) $10 \%$, (c) $21.06 \%$, (d) $50 \%$, and (e) $100 \%$. 


\subsection{Cathode Side: Effect of Solubility of $\mathrm{O}_{2}$ in the Electrolyte}

Gaseous $\mathrm{O}_{2}$ is provided as a reactant into the cathode side from external sources, and it dissolves in the electrolyte first and diffuses into the reaction sites in the porous electrode to undergo electrochemical reactions. Therefore, the amount of $\mathrm{O}_{2}$ available at the reaction sites will be affected significantly by its solubility in the electrolyte, indicating the $\mathrm{O}_{2}$ solubility will be a critical factor in improving cell performance. In this study, the effect of solubility, or the fraction of maximum $\mathrm{O}_{2}$ concentration in the cathode (of which thickness and porosity are $195 \mu \mathrm{m}$ and 0.73 , respectively) over atmospheric $\mathrm{O}_{2}$ concentration was analyzed for the cases of 0.2 and $0.8 \mathrm{O}_{2}$ solubilities at the current density of $1 \mathrm{~A} / \mathrm{m}^{2}$.

As illustrated in Figure 8, the porosity distribution in the cathode electrode was measured over the normalized thickness of the electrode during operation from $0 \%$ to $100 \%$ discharge. The initial porosity was 0.73 at $0 \%$ discharge, and it decreased as the cell operated. This is because $\mathrm{Al}_{2} \mathrm{O}_{3}$, which is the discharge product, is precipitated in the electrode once it reaches its solubility limit in the electrolyte. Therefore, this porosity plot can be used to predict the distribution of electrochemical reactions over the porous electrode.
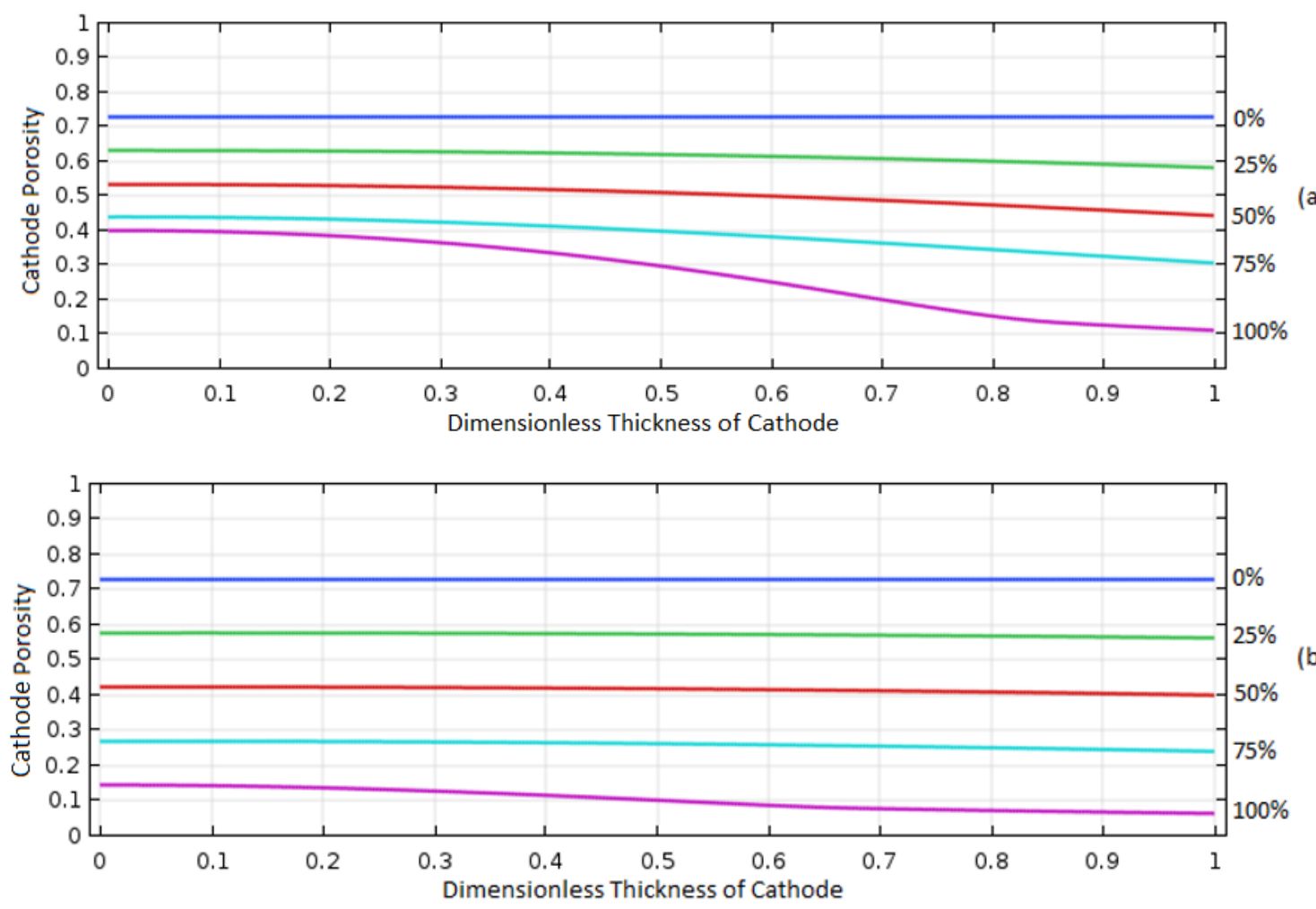

Figure 8. Distribution of cathode porosity from $0 \%$ to $100 \%$ discharge at $1 \mathrm{~A} / \mathrm{m}^{2}$ current density for $\mathrm{O}_{2}$ solubilities of (a) 0.2 and (b) 0.8 in the electrolyte, with a cathode electrode of which thickness and porosity are $195 \mu \mathrm{m}$ and 0.73 , respectively.

For the case of 0.2 solubility, porosity was decreased uniformly over the cathode thickness until it reached around 0.5 , and then the porosity change was made mainly in the regions in the right (i.e., position of the dimensionless thickness is 1 in Figure 8a) which exposes to the $\mathrm{O}_{2}$ supply. It indicates that all the areas of electrode were uniformly used for the cell reaction until the porosity reached around 0.5 , and then the reaction dominantly occurred near the right side of cathode facing the $\mathrm{O}_{2}$ supply. This behavior can be understood with the characteristic behavior of diffusive transport of $\mathrm{O}_{2}$ and the effect of precipitated $\mathrm{Al}_{2} \mathrm{O}_{3}$ in the electrode. As the porosity in the electrode decreased, the $\mathrm{O}_{2}$ diffusion rate decreased due to the decrease of electrolyte volume available for the $\mathrm{O}_{2}$ transport and the increase of tortuosity of the transport path in the porous electrode, impeding $\mathrm{O}_{2}$ from traveling to 
the left side of the electrode-facing membrane. Thus, the reaction sites moved to the regions close to the $\mathrm{O}_{2}$ supply where enough $\mathrm{O}_{2}$ was available.

As the $\mathrm{O}_{2}$ solubility in the electrolyte increased to 0.8 , the increased supply of oxygen allowed for increased $\mathrm{O}_{2}$ species diffusion to the reaction sites to the left of the electrode, allowing the electrochemical reaction to occur more uniformly over the entire region of electrode until a final porosity of 0.18 was reached.

The effect of the $\mathrm{O}_{2}$ solubility on discharge performance is illustrated in Figure 9. The overall cell potential was greater for the higher $\mathrm{O}_{2}$ solubility because of the increased amount of $\mathrm{O}_{2}$ in the reaction sites, and the discharge capacity increased as the solubility increased (554 Ah/m $\mathrm{m}^{2}$ for solubility $0.2,686 \mathrm{Ah} / \mathrm{m}^{2}$ for $0.4,738 \mathrm{Ah} / \mathrm{m}^{2}$ for 0.6 , and $767 \mathrm{Ah} / \mathrm{m}^{2}$ for 0.8 ) due to the increased area of porous electrode available for the cell reaction, as described previously.

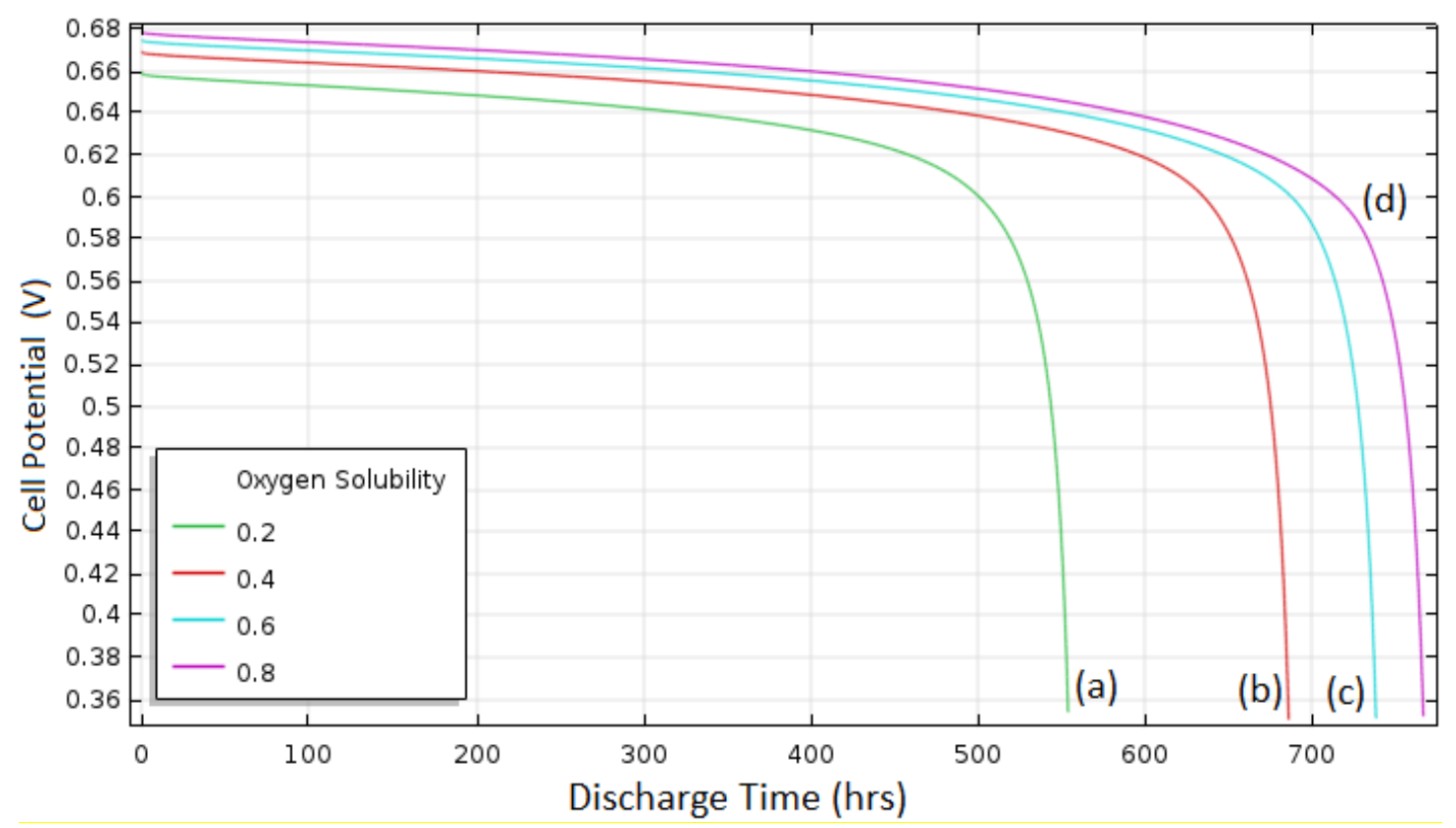

Figure 9. Discharge curves at $1 \mathrm{~A} / \mathrm{m}^{2}$ for $\mathrm{O}_{2}$ solubilities of (a) 0.2 , (b) 0.4 , (c) 0.6 , and (d) 0.8 , with a cathode electrode of which thickness and porosity are $195 \mu \mathrm{m}$ and 0.73 , respectively.

\subsection{Cathode Side: Effect of Properties (Porosity and Thickness) of the Porous Electrode}

\subsubsection{Effect of Porosity}

Understanding of the effect of properties of the porous electrode on the cell performance is very important to design and operate the cell optimally, and thus in this study the effect of initial porosity of the porous electrode was investigated for the cases of $0.2,0.4,0.6,0.73,0.8,0.9$, and 0.94 initial porosities. Figure 10 shows the porosity distribution for the 0.2 and 0.94 porosity cases during discharge at $1 \mathrm{~A} / \mathrm{m}^{2}$. For the case of 0.2 initial porosity, the porosity decreased almost entirely on the right side of the electrode where the $\mathrm{O}_{2}$ was introduced, indicating the areas away from $\mathrm{O}_{2}$ inlet were not used for the cell reaction due to the limited diffusion of $\mathrm{O}_{2}$ caused by the deposition of $\mathrm{Al}_{2} \mathrm{O}_{3}$ on the cathode. However, for the case of 0.93 initial porosity, the distribution of the deposited $\mathrm{Al}_{2} \mathrm{O}_{3}$ was much more even due to the greater electrolyte volume for $\mathrm{O}_{2}$ diffusion.

The effect of the initial porosity on discharge curves is shown in Figure 11. With increasing initial porosity, the discharge time increased. The poor performance was obtained for the case of the 0.2 initial porosity, where the uneven and limited deposition of $\mathrm{Al}_{2} \mathrm{O}_{3}$ (i.e., cell reaction) was in accordance with a low discharge capacity. However, the capacity started to decrease as the initial porosity was greater than about 0.94 , which may have been caused by reduction in active surface area and structural instability in the cathode [17]. 

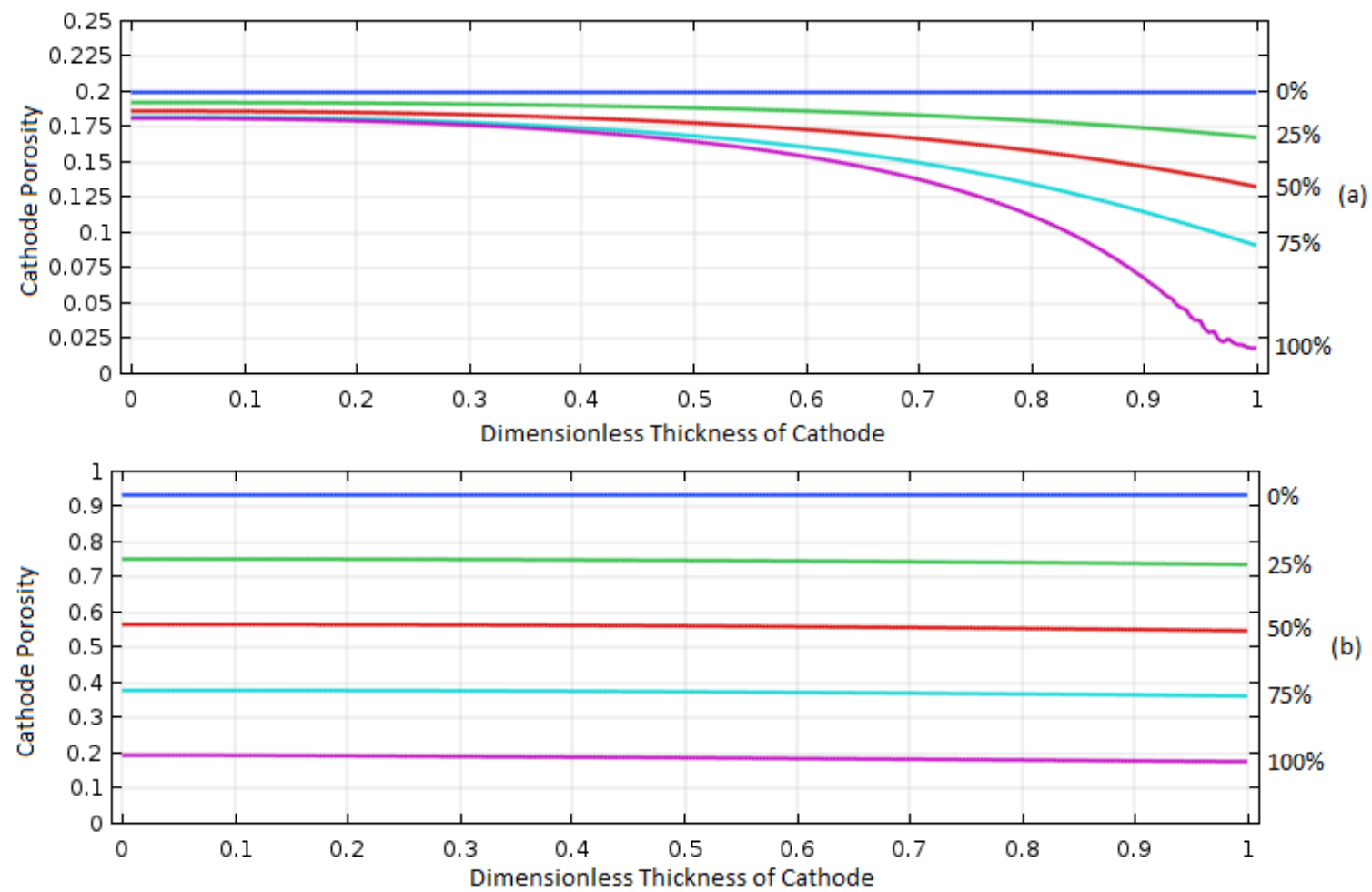

Figure 10. Distribution of cathode porosity from $0 \%$ to $100 \%$ discharge at $1 \mathrm{~A} / \mathrm{m}^{2}$ for initial porosities of (a) 0.2 and (b) 0.94 , with $0.5 \mathrm{O}_{2}$ solubility and $195 \mu \mathrm{m}$ cathode thickness.

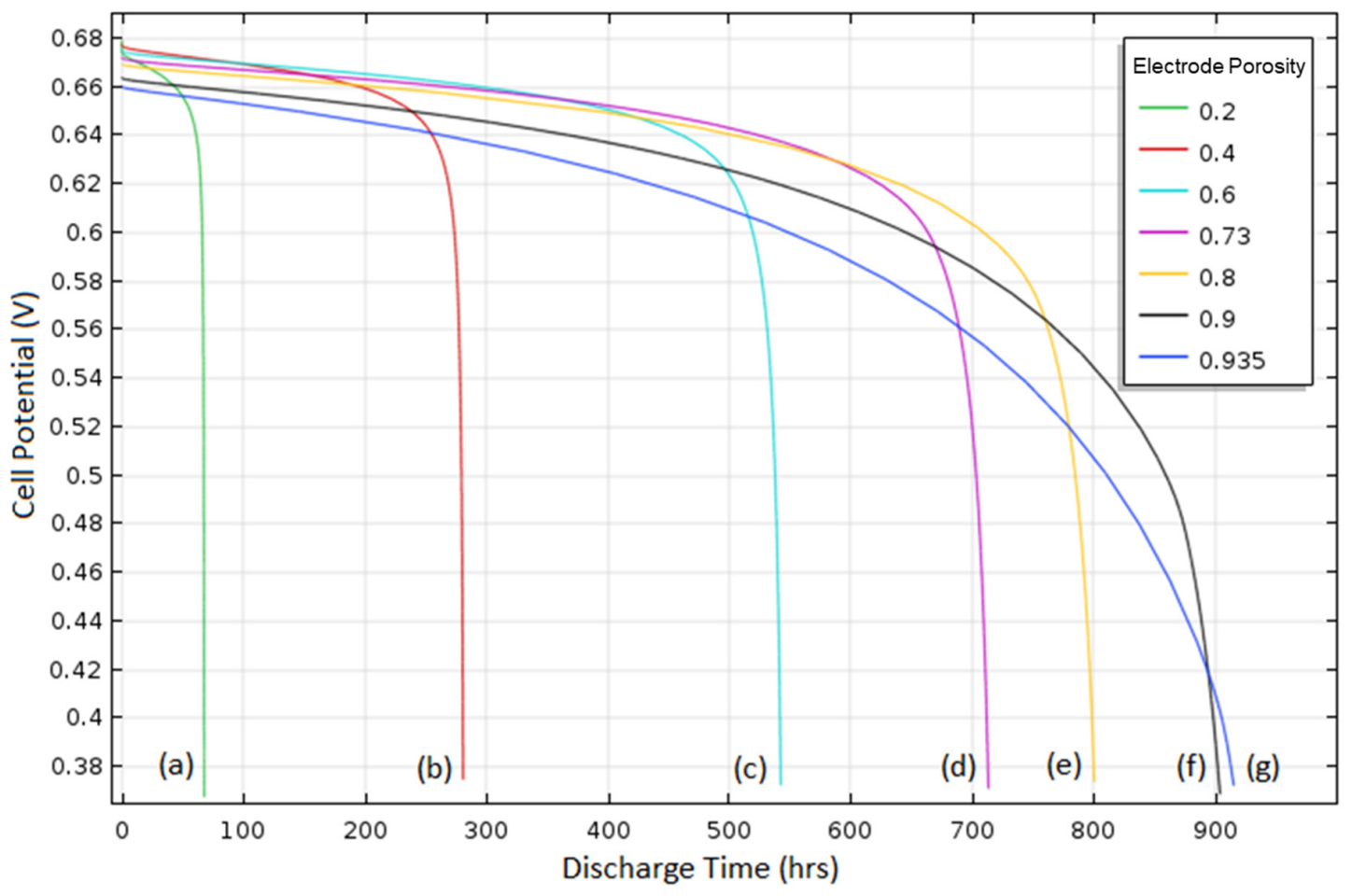

Figure 11. Discharge curves at $1 \mathrm{~A} / \mathrm{m}^{2}$ for initial porosities of (a) 0.2 , (b) 0.4 , (c) 0.6 , (d) 0.73 , (e) 0.8 , (f) 0.9 , and (g) 0.935 , with $0.5 \mathrm{O}_{2}$ solubility and $195 \mu \mathrm{m}$ cathode thickness. 
4.6.2. Effect of thickness of the porous electrode

Various thicknesses $(25,50,100,195,400,800,1600 \mu \mathrm{m})$ of the cathode were investigated at $1 \mathrm{~A} / \mathrm{m}^{2}$ discharge with $0.49 \mathrm{O}_{2}$ solubility and 0.73 initial porosity to determine the effect of cathode thickness. Figure 12 shows the porosity distribution over discharge for thicknesses of $25 \mu \mathrm{m}$ and $1600 \mu \mathrm{m}$. For the $25 \mu \mathrm{m}$ case, the porosity distribution was roughly even across the cathode during the entirety of discharge. Because of the short distance for the diffusion of $\mathrm{O}_{2}$, the entire cathode was used for its potential capacity. For the $1600 \mu \mathrm{m}$ case, the distribution was uneven and there was almost no $\mathrm{Al}_{2} \mathrm{O}_{3}$ deposition on the left-hand side of the cathode. The long distance for $\mathrm{O}_{2}$ to diffuse through the cathode caused lower $\mathrm{O}_{2}$ concentrations in the far end of the cathode, leading to less deposition and inefficient use of the cathode surface area.
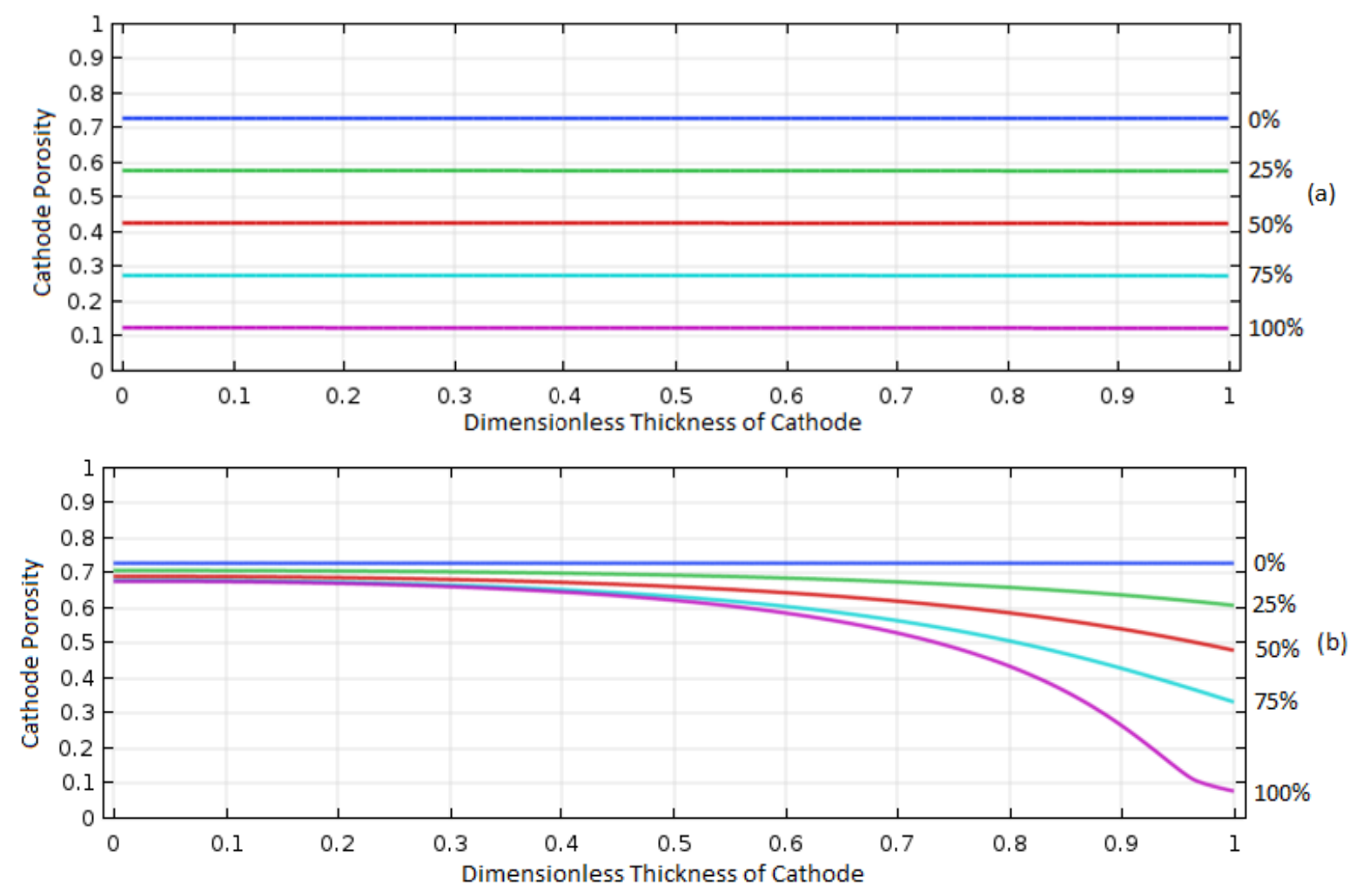

Figure 12. Distribution of cathode porosity from $0 \%$ to $100 \%$ discharge at $1 \mathrm{~A} / \mathrm{m}^{2}$ current density for (a) $25 \mu \mathrm{m}$ and (b) $1600 \mu \mathrm{m}$ cathode thickness, with $0.49 \mathrm{O}_{2}$ solubility and 0.73 cathode porosity.

The discharge curves for different cathode thicknesses are shown in Figure 13. For smaller thicknesses, the increase in cathode thickness caused a roughly proportional increase in battery capacity. At these small thicknesses, all the pore regions in the cathode were considered to be filled almost completely with $\mathrm{Al}_{2} \mathrm{O}_{3}$, providing the maximum possible battery capacity. However, at larger cathode thicknesses, increasing the cathode thickness provided diminishing returns on capacity due to the aforementioned long distance for $\mathrm{O}_{2}$ diffusion and resulting uneven $\mathrm{Al}_{2} \mathrm{O}_{3}$ deposition.

When designing the cathode, the tradeoff is whether to use a small thickness with efficient but low capacity or use a large thickness with higher capacity but inefficient use of the cathode porous area. The optimal cathode thickness can be determined by the Damköhler number,

$$
D a=\frac{j L}{n F D_{\mathrm{O}_{2}}^{e f f} c_{\mathrm{O}_{2}}}
$$


The Damköhler number represents the ratio of $\mathrm{O}_{2}$ electrochemical reaction at the cathode and the diffusion of $\mathrm{O}_{2}$ to reach the reacting surface. For optimal design of the cathode electrode, a Damköhler number of unity is desired. The ideal thickness was determined by comparing the specific capacities of different cathode thicknesses. For the Al-air battery, a cathode thickness of roughly $40-60 \mu \mathrm{m}$ provided the maximum possible specific capacity of roughly $6850 \mathrm{C} / \mathrm{kg}$ of carbon at $1 \mathrm{~A} / \mathrm{m}^{2}$. In this range, the maximum amount of $\mathrm{Al}_{2} \mathrm{O}_{3}$ (relative to cathode size) was deposited, so the diffusion and reaction of $\mathrm{O}_{2}$ throughout the cathode were roughly equal, meaning the Damköhler number in this range is unity.

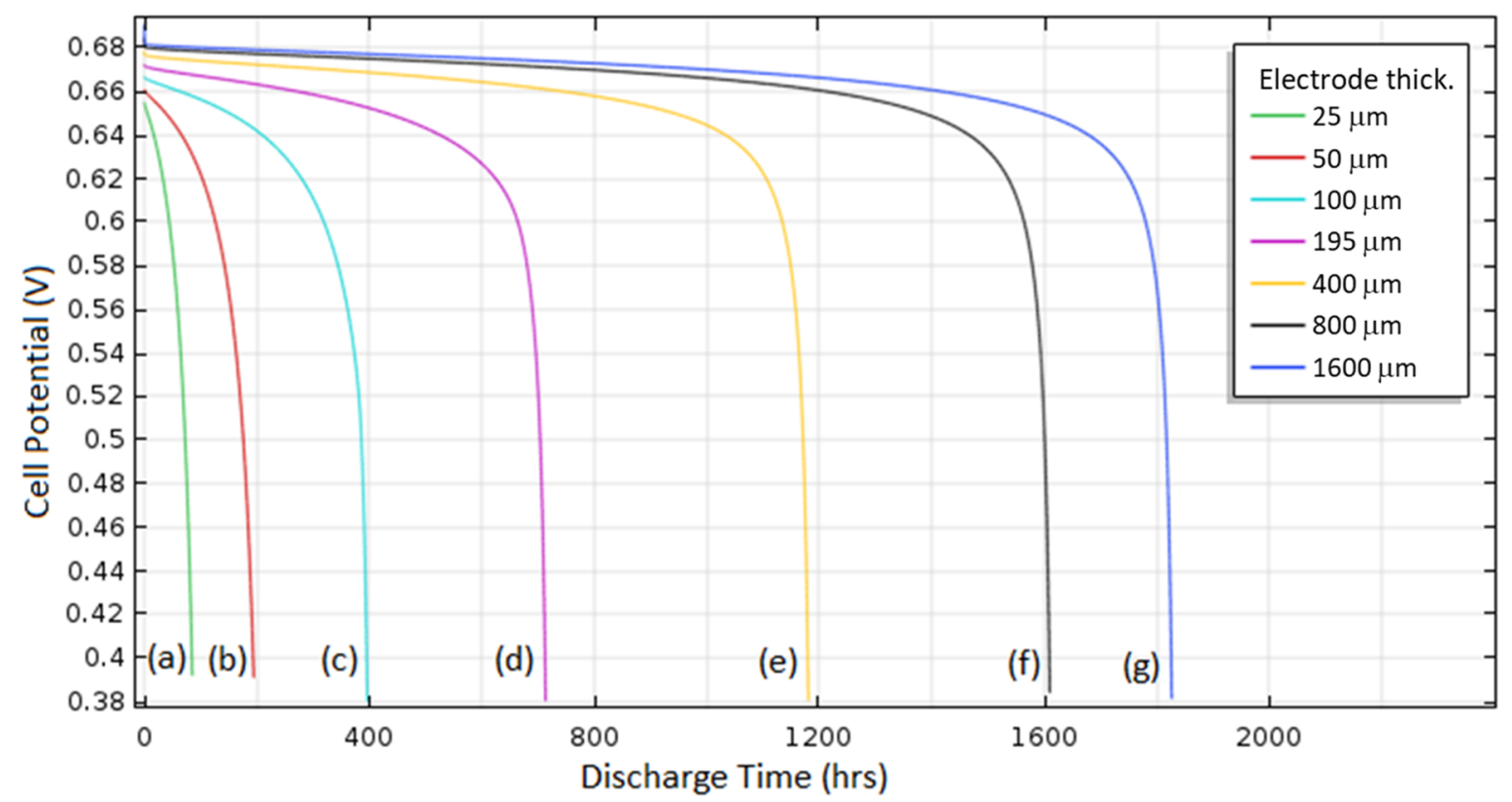

Figure 13. Discharge curves at $1 \mathrm{~A} / \mathrm{m}^{2}$ for cathode thicknesses of (a) 25, (b) 50, (c) 100, (d) 195, (e) 400, (f) 800 , and (g) $1600 \mu \mathrm{m}$, with $0.49 \mathrm{O}_{2}$ solubility and 0.73 cathode porosity.

\section{Conclusions}

In this research, we have revisited the promising aluminum-air (oxygen) battery system to investigate the challenging issues such as $\mathrm{H}_{2}$ evolution as a side reaction and oxide film formation on the surface of aluminum that hinder the practical application of these batteries. An electrolyte based on nonaqueous ionic liquid [EmIm] Cl with $\mathrm{AlCl}_{3}$ was utilized, and to understand the key controlling parameters for the Al-air system, systematic research was conducted through ex situ component-level and in situ cell OCV tests, thermodynamic-based analysis, and physics-based modeling.

From the ex situ/in situ tests and thermodynamic-based analysis, it was found that a key parameter to control growth of the inert oxide film is the surface tension, which could be controlled by using proper amount of chloride ions in the electrolyte, and the cracks were formed on the oxide film by $21 \%$ when it was submerged into the electrolyte of molar ratio 1:1.5 of $[\mathrm{EmIm}] \mathrm{Cl}$ and $\mathrm{AlCl}_{3}$, which is the electrolyte condition utilized in most research $[7,19,33]$. 
The physics-based modeling was developed to analyze the effect of $\mathrm{Al}_{2} \mathrm{O}_{3}$ formation on the anode and cathode sides. The effect of the oxide film on anode overpotential was significant, and overpotential (voltage loss) for the film cracked by $21 \%$ was predicted to be $30 \%$ greater than that of no film covering the $\mathrm{Al}$ anode surface.

For the cathode side, the effect of $\mathrm{O}_{2}$ solubility in the electrolyte was analyzed with the porosity plot, and only areas of the porous electrode close to $\mathrm{O}_{2}$ inlet were used for the cell reaction when the solubility is low, decreasing the capacity of cell. As the solubility increased, more of the areas in the electrode could be used, resulting in higher capacity.

Furthermore, the effect of properties (i.e., porosity and thickness) of the porous electrode was also investigated, and it was found that the initial porosity significantly affected the reaction distribution over the electrode thickness and cell charge capacity due to the porosity effect on diffusive transport of $\mathrm{O}_{2}$, and as the porosity increased, more uniform distribution of reaction was found over the electrode. Thickness effect of the porous electrode was investigated, and for the thinner electrode, more uniform distribution of reaction over the electrode was found, but charge capacity itself was low. However, as thickness increased, the charge capacity increased, but the uniformity of the reaction over the electrode decreased, decreasing utilization of the area of the porous electrode.

Comparisons of specific capacity at different cathode thicknesses were used to define the optimal design of the cathode. It was found that a cathode thickness of roughly $40-60 \mu \mathrm{m}$ gave optimal performance at $1 \mathrm{~A} / \mathrm{m}^{2}, 0.49 \mathrm{O}_{2}$ solubility, and 0.73 cathode porosity, which provides a maximum specific capacity of roughly $6800 \mathrm{C} / \mathrm{kg}$ of carbon cathode material. The Damköhler number, the ratio of $\mathrm{O}_{2}$ electrochemical reaction at the cathode and the diffusion of $\mathrm{O}_{2}$ to reach the reacting surface, is unity in this range.

This research provides the first modeling analysis of the ionic liquid-based Al-air battery, which is a new system with limited availability of parameters and experimental results in literature, and thus parameter values assumed from similar systems were utilized, leading to some inaccurate predictions in certain operating conditions. Nonetheless, the developed model successfully predicted overall cell performance and behaviors, providing insight into the characteristic cell reaction and key controlling parameters to mitigate the effect of aluminum oxide formation. Thus, it is expected that the results from this research will be used as key information to guide future research and development of the $\mathrm{Al}$-air $\left(\right.$ or $\mathrm{O}_{2}$ ) cell system.

Author Contributions: Conceptualization, A.K.M., C.W., N.S.H. and K.T.C.; methodology, A.K.M. and N.S.H.; software, C.W.; validation, A.K.M., C.W. and T.C.; formal analysis, A.K.M., C.W. and T.C.; investigation, A.K.M., C.W. and T.C.; resources, L.Z. and T.C.; data curation, A.K.M. and C.W.; writing-original draft preparation, C.W. and A.K.M.; writing-review and editing, N.S.H., L.Z. and T.C.; supervision, N.S.H. and T.C.; project administration, N.S.H., L.Z. and T.C. All authors have read and agreed to the published version of the manuscript.

Funding: This research was partially supported by a Research and Artistry grant from Northern Illinois University (NIU). The process fee for the publication was supported by the NIU library. This work is also supported by Laboratory Directed Research and Development (LDRD) funding from Argonne National Laboratory, provided by the Director, Office of Science, U.S. Department of Energy, under Contract No. DE-AC02-06CH11357.

Acknowledgments: Authors acknowledge Professor Xu, NIU chemistry department, for supporting SEM.

Conflicts of Interest: The authors declare no conflict of interest, and the funders had no role in the design of the study; in the collection, analyses, or interpretation of data; in the writing of the manuscript, or in the decision to publish the results. 


\section{Nomenclature}

A Surface area $\quad \mathrm{m}^{2}$

C Concentration $\mathrm{mol} / \ell$

D Diffusivity $\mathrm{m}^{2} / \mathrm{s}$

Da Damköhler number -

E Equilibrium potential V

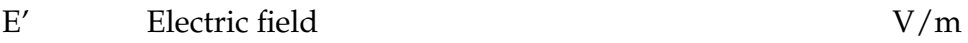

F Faraday's constant $\quad \mathrm{C} / \mathrm{mole}^{-}$

I Total current A

i Current density $\mathrm{A} / \mathrm{m}^{2}$

1 Thickness $\mathrm{m}$

M Molecular weight $\mathrm{kg} / \mathrm{kgmol}$

$\mathrm{n} \quad$ Number of electron $\quad \mathrm{e}^{-}$mole

$\mathrm{p} \quad$ Pressure $\mathrm{Pa}$

q Geometric factor for the morphology -

$\mathrm{r}_{0} \quad$ Radius of a particle in porous electrode $\mathrm{m}$

$\mathrm{r} \quad$ Electrochemical reaction rate $\mathrm{mol} / \mathrm{s} \cdot \mathrm{m}^{2}$

$\mathrm{T} \quad$ Temperature $\mathrm{K}$

V Volume $\mathrm{m}^{3}$

$X \quad$ Phase function -

Greek

$\alpha \quad$ Charge transfer coefficient

$\Gamma \quad$ Quantity adsorbed on the metal surface

Surface tension

Volume fraction

Dielectric constant

Vacuum permittivity

Overpotential

Liquid ionic conductivity

$-$

Chemical potential

$\mathrm{mol} / \mathrm{m}^{2}$

$\mathrm{N} / \mathrm{m}$

$-$

$\mathrm{F} / \mathrm{m}$

$\mathrm{V}$

$\mathrm{S} / \mathrm{m}$

$\mathrm{J} / \mathrm{mol}$

Number of ionic species dissociated from a salt

$\mathrm{kg} / \mathrm{m}^{3}$

Density

Solid electronic conductivity

$\mathrm{S} / \mathrm{m}$

$\mathrm{V}$

$\mathrm{m} / \mathrm{s}$

Subscript

Quantity representing a phase

Velocity of a surface

Anode

$\begin{array}{cc}\text { app } & \text { Applied } \\ \text { c } & \text { Cathode }\end{array}$

cell Full cell

D Diffusion

e Electrolyte phase

film Film

j Species $\mathrm{j}$

k Phase $\mathrm{k}$

$\mathrm{m} \quad$ Phase $\mathrm{m}$

n Normal

o Initial state

s Solid phase

Superscript

eff Effective

0 Standard state 


\section{Appendix A}

\section{A.1. Mass and Species Conservation Equations}

Microscopic equation of mass conservation is described:

$$
\frac{\partial \rho_{k}}{\partial t}+\nabla \cdot\left(\rho_{k} \mathbf{v}_{k}\right)=0
$$

where $\rho$ and $\mathbf{v}$ are the density and velocity in the phase $\mathrm{k}$.

After applying the volume average methods (i.e., Equations (4)-(8)) into Equation (A1), macroscopic mass conservation equation can be obtained [14,40]:

$$
\frac{\partial\left(\varepsilon_{k} \rho_{k}\right)}{\partial t}+\nabla \cdot\left(\varepsilon_{k} \rho_{k}\left\langle\mathbf{v}_{\mathbf{k}}\right\rangle^{k}\right)=\frac{1}{V_{0}} \int_{A_{k m}} \rho_{k}\left(\mathbf{w}_{\mathrm{k}}-\mathbf{v}_{\mathrm{k}}\right) \cdot \mathbf{n}_{\mathrm{k}} d A \cong \frac{A_{k m}}{V_{0}} \rho_{k} \bar{w}_{n, k m}=a_{k m} \rho_{k} \bar{w}_{n, k m}
$$

where $A_{k m}$ is the total interfacial area between $\mathrm{k}$ and $\mathrm{m}$ phases, $a_{\mathrm{km}}$ denotes the specific area of the $\mathrm{k}-\mathrm{m}$ interface, $\bar{w}_{n, k m}$ is average normal velocity of $\mathrm{k}-\mathrm{m}$ interface relative to phase $\mathrm{k}$ and directing outward from phase $\mathrm{k}$.

\section{A.2. Microscopic Conservation of Species is Described}

$$
\frac{\partial c_{k}}{\partial t}=-\nabla \cdot \mathbf{N}_{k}
$$

where $c_{k}$ and $\mathbf{N}_{k}$ are the concentration and molar flux of a species in phase $\mathrm{k}$, respectively.

Molar flux of a species in phase $\mathrm{k}$ is represented by

$$
\mathbf{N}_{k}=-D_{k} \nabla c_{k}+\frac{t_{k}}{z F} \mathbf{i}_{k}+c_{k} \mathbf{v}_{k}
$$

where $D_{k}, t_{k}$, and $\mathrm{z}$ are the diffusivity, transference number, and charge number of a species in phase $\mathrm{k}$, respectively, $F$ and $\mathbf{i}_{k}$ denote the Faraday constant and current density in the phase k.

From the species balance at the interface between phases $\mathrm{k}$ and $\mathrm{m}$, the relative flux of ion in each phase is related by production rate (i.e., $r_{k m}$ ) of species at the $\mathrm{k}-\mathrm{m}$ interface [14]:

$$
\left(\mathbf{N}_{k}-c_{k} \mathbf{w}_{\mathrm{k}}\right) \cdot \mathbf{n}_{\mathrm{k}}+\left(\mathbf{N}_{m}-c_{m} \mathbf{w}_{\mathrm{m}}\right) \cdot \mathbf{n}_{\mathrm{m}}=-r_{k m}
$$

It is simplified further under the assumption of ionic species existing only in one side of the interface (i.e., in phase k) for the general battery cases:

$$
\left(\mathbf{N}_{k}-c_{k} \mathbf{w}_{\mathrm{k}}\right) \cdot \mathbf{n}_{\mathrm{k}}=-r_{k m}
$$

By applying the volume average method into Equation (A3),

$$
\frac{\partial\left\langle c_{k}\right\rangle}{\partial t}=-\nabla \cdot\left\langle\mathbf{N}_{k}\right\rangle-\frac{1}{V_{0}} \int_{A_{k m}}\left(\mathbf{N}_{k}-c_{k} \mathbf{w}_{\mathrm{k}}\right) \cdot \mathbf{n}_{\mathrm{k}} d A
$$

After applying volume average to Equation (A4) with the assumption of no hydrodynamic dispersion due to variation of microscopic velocity and species concentration,

$$
\left\langle\mathbf{N}_{k}\right\rangle=-\varepsilon_{k} D_{k} \nabla\left\langle c_{k}\right\rangle^{k}+\frac{t_{k}}{z F}\left\langle\mathbf{i}_{k}\right\rangle+\varepsilon_{k}\left\langle c_{k}\right\rangle^{k}\left\langle\mathbf{v}_{k}\right\rangle^{k}
$$

By substituting (A8) into (A7),

$$
\begin{gathered}
\frac{\partial\left\langle\varepsilon_{k}\left\langle c_{k}\right\rangle^{k}\right\rangle}{\partial t}+\nabla \cdot\left(\varepsilon_{k}\left\langle c_{k}\right\rangle^{k}\left\langle\mathbf{v}_{k}\right\rangle^{k}\right) \\
=\nabla \cdot\left(D_{k}^{e f f} \nabla\left\langle c_{k}\right\rangle^{k}\right)-\nabla \cdot\left(\frac{t_{k}}{z F}\left\langle\mathbf{i}_{k}\right\rangle\right)+\frac{1}{V_{0}} \int_{A_{k m}} D_{k} \nabla c_{k} \cdot \mathbf{n}_{\mathrm{k}} d A \\
-\frac{1}{V_{0}} \int_{A_{k m}} \frac{t_{k}}{z F} \mathbf{i}_{k} \cdot \mathbf{n}_{\mathrm{k}} d A+\frac{1}{V_{0}} \int_{A_{k m}} c_{k}\left(\mathbf{w}_{\mathrm{k}}-\mathbf{v}_{\mathrm{k}}\right) \cdot \mathbf{n}_{\mathrm{k}} d A
\end{gathered}
$$


After volume average, Equation (A6) becomes;

$$
\frac{1}{V_{0}} \int_{A_{k m}}\left(-D_{k} \nabla c_{k}+\frac{t_{k}}{z F} \mathbf{i}_{k}+c_{k} \mathbf{v}_{\mathrm{k}}-c_{k} \mathbf{w}_{\mathrm{k}}\right) \cdot \mathbf{n}_{\mathrm{k}} d A=-a_{k m} \bar{r}_{k m}=a_{k m} \sum_{j} \frac{s_{j}}{n_{j} F} \bar{i}_{n j}
$$

where $s, n$, and $\bar{i}_{n}$ are the stoichiometric coefficient of reactive species, the number of electrons, and the average transfer current density of reaction $j$ taking place at the interface, respectively.

The second term in the right-hand side of Equation (A9) can be rearranged with Equation (A18):

$$
\nabla \cdot\left(\frac{t_{k}}{z F} \mathbf{i}_{k}\right)=\frac{t_{k}}{z F} \nabla \cdot \mathbf{i}_{k}=-\frac{t_{k}}{z F} \frac{1}{V_{0}} \int_{A_{k m}} \mathbf{i}_{k} \cdot \mathbf{n}_{k} d A \cong-a_{k m} \sum_{j}\left(\frac{t_{k}}{z F}\right) \bar{i}_{n j}
$$

By substituting Equation (A10) and (A11) into (A9), the final form of macroscopic species conservation is obtained:

$$
\frac{\partial\left\langle\varepsilon_{k}\left\langle c_{k}\right\rangle^{k}\right\rangle}{\partial t}+\nabla \cdot\left(\varepsilon_{k}\left\langle c_{k}\right\rangle^{k}\left\langle\mathbf{v}_{k}\right\rangle^{k}\right)=\nabla \cdot\left(D_{k}^{e f f} \nabla\left\langle c_{k}\right\rangle^{k}\right)-a_{k m} \sum_{j}\left(\frac{t_{k}}{z F}+\frac{s_{j}}{n_{j} F}\right) \bar{i}_{n j}
$$

where $D_{k}^{e f f}$ is $\varepsilon_{k} D_{k}$.

\section{A.3. Charge Conservation Equation}

Electrochemical reactions take place at the interface between $\mathrm{k}$ and $\mathrm{m}$ phases, and thus no charge is generated or consumed within each phase:

$$
\nabla \cdot \mathbf{i}_{k}=0
$$

The interface boundary condition is

$$
\mathbf{i}_{k} \cdot \mathbf{n}_{k}=-\sum_{j} i_{n j}
$$

where $\mathbf{i}_{k}$ is current density in phase $\mathrm{k}$ (i.e., superficial current density) and $i_{n j}$ is transfer current density of reaction $\mathrm{j}$ taking place at the interface.

In solid materials, the current density $\left(\mathbf{i}_{s}\right)$ is determined by solid electronic conductivity $(\sigma)$ and electric potential $\left(\varphi_{s}\right)$ the in solid phase:

$$
\mathbf{i}_{s}=-\sigma \nabla \varphi_{s}
$$

In the electrolyte, the current density $\left(\mathbf{i}_{e}\right)$ is affected by migration and diffusion of ionic species, and the relation for a concentrated binary electrolyte can be described [41]:

$$
\mathbf{i}_{e}=-k \nabla \varphi_{e}-k_{D} \nabla\left(\ln c_{e}^{j}\right)
$$

where $k$ is the conductivity of the electrolyte, superscript $j$ denotes ionic species (+ for cation and - for anion), and $k_{D}$ is diffusion conductivity to account for the rate of charged particle motion due to diffusion of ionic species which is defined [41]:

$$
k_{D}=\frac{v R T k}{F}\left(\frac{s_{j}}{n v_{j}}+\frac{t_{j}^{0}}{z_{j} v_{j}}-\frac{s_{0} c_{e}}{n c_{0}}\right)\left(1+\frac{d \ln f_{ \pm}}{d \ln c_{e}}\right)
$$

where $v_{j}$ and $v$ denote number of ionic species (i.e., cation and anion) and total moles of ions into which a molecule of electrolyte dissociates, $s_{j}$ and $s_{0}$ denote stoichiometric coefficients of ionic species and solvent, $c_{e}$ and $c_{0}$ are concentrations of electrolyte and solvent, $n$ is the number of electrons, $z_{j}$ is the charge number of ionic species, $t_{j}^{0}$ is transference number of ions with respect to solvent velocity, and $f_{ \pm}$is mean molar activity coefficient.

Macroscopic charge conservation equation is obtained by taking the volume average of equation (A13);

$$
\left\langle\nabla \cdot \mathbf{i}_{k}\right\rangle=\nabla \cdot\left\langle\mathbf{i}_{k}\right\rangle+\frac{1}{V_{0}} \int_{A_{k m}} \mathbf{i}_{k} \cdot \mathbf{n}_{k} d A=0
$$

where

$$
\frac{1}{V_{0}} \int_{A_{k m}} \mathbf{i}_{k} \cdot \mathbf{n}_{k} d A \cong a_{k m} \sum_{j} \bar{i}_{n j}
$$

Thus,

$$
\nabla \cdot\left\langle\mathbf{i}_{k}\right\rangle+a_{k m} \sum_{j} \bar{i}_{n j}=0
$$


The macroscopic equation for the solid phase is obtained from volume average of Equation (A15):

$$
\nabla \cdot\left(\sigma^{e f f} \nabla\left\langle\varphi_{S}\right\rangle^{s}\right)+\left.a_{s e} \sum_{j} \bar{i}_{n j}\right|_{s}=0
$$

Similarly, the macroscopic equation for the electrolyte phase is obtained from Equation (A16):

$$
\nabla \cdot\left(k^{e f f} \nabla\left\langle\varphi_{e}\right\rangle^{e}\right)+\nabla \cdot\left(k_{D}^{e f f} \nabla \ln \left\langle c_{e}^{i}\right\rangle^{e}\right)+\left.a_{s e} \sum_{j} \bar{i}_{n j}\right|_{e}=0
$$

where the interfacial current density at the solid and electrolyte interface is related by

$$
\left.a_{s e} \sum_{j} \bar{i}_{n j}\right|_{e}=-\left.a_{s e} \sum_{j} \bar{i}_{n j}\right|_{s}
$$

\section{References}

1. Li, Q.; Bjerrum, N.J. Aluminum as anode for energy storage and conversion: A review. J. Power Sources 2002, 110, 1-10. [CrossRef]

2. Yang, S.; Knickle, H. Design and analysis of aluminum/air battery system for electric vehicles. J. Power Sources 2002, 112, 162-173. [CrossRef]

3. Egan, D.R.; Ponce de León, C.; Wood, R.J.K.; Jones, R.L.; Stokes, K.R.; Walsh, F.C. Developments in electrode materials and electrolytes for aluminium-air batteries. J. Power Sources 2013, 236, 293-310. [CrossRef]

4. Gelman, D.; Shvartsev, B.; Ein-Eli, Y. Aluminum-air battery based on an ionic liquid electrolyte. J. Mater. Chem. A 2014, 2, 20237-20242. [CrossRef]

5. Xia, S.; Zhang, X.-M.; Huang, K.; Chen, Y.-L.; Wu, Y.-T. Ionic liquid electrolytes for aluminium secondary battery: Influence of organic solvents. J. Electroanal. Chem. 2015, 757, 167-175. [CrossRef]

6. Liu, Y.; Sun, Q.; Li, W.; Adair, K.R.; Li, J.; Sun, X. A comprehensive review on recent progress in aluminum-air batteries. Green Energy Environ. 2017, 2, 246-277. [CrossRef]

7. Revel, R.; Audichon, T.; Gonzalez, S. Non-aqueous aluminium-air battery based on ionic liquid electrolyte. J. Power Sources 2014, 272, 415-421. [CrossRef]

8. Wu, F.; Zhu, N.; Bai, Y.; Gao, Y.; Wu, C. An interface-reconstruction effect for rechargeable aluminum battery in ionic liquid electrolyte to enhance cycling performances. Green Energy Environ. 2018, 3, 71-77. [CrossRef]

9. Gelman, D.; Shvartsev, B.; Wallwater, I.; Kozokaro, S.; Fidelsky, V.; Sagy, A.; Oz, A.; Baltianski, S.; Tsur, Y.; Ein-Eli, Y. An aluminum-ionic liquid interface sustaining a durable Al-air battery. J. Power Sources 2017, 364, 110-120. [CrossRef]

10. Marma, K.; Kolli, J.; Cho, K.T. Membrane-Less Hydrogen Iron Redox Flow Battery. J. Electrochem. En. Conv. Stor. 2018, 16, 011005. [CrossRef]

11. Schoetz, T.; de Leon, C.P.; Ueda, M.; Bund, A. Perspective-State of the Art of Rechargeable Aluminum Batteries in Non-Aqueous Systems. J. Electrochem. Soc. 2017, 164, A3499. [CrossRef]

12. Whitaker, S. ADVANCES IN THEORY OF FLUID MOTION IN POROUS MEDIA. Ind. Eng. Chem. 1969, 61, 14-28. [CrossRef]

13. Whitaker, S. The Method of Volume Averaging; Theory and Applications of Transport in Porous Media; Springer: Cham, The Netherlands, 1999; ISBN 978-0-7923-5486-4.

14. Wang, C.Y.; Gu, W.B.; Liaw, B.Y. Micro-Macroscopic Coupled Modeling of Batteries and Fuel Cells I. Model Development. J. Electrochem. Soc. 1998, 145, 3407-3417. [CrossRef]

15. Bruggeman, D.A.G. Berechnung verschiedener physikalischer Konstanten von heterogenen Substanzen. I. Dielektrizitätskonstanten und Leitfähigkeiten der Mischkörper aus isotropen Substanzen. Ann. Der Phys. 1935, 416, 636-664. [CrossRef]

16. Rueden, C.T.; Schindelin, J.; Hiner, M.C.; DeZonia, B.E.; Walter, A.E.; Arena, E.T.; Eliceiri, K.W. ImageJ2: ImageJ for the next generation of scientific image data. BMC Bioinform. 2017, 18, 529. [CrossRef] [PubMed]

17. LaFollette, R.M.; Bennion, D.N. Design Fundamentals of High Power Density, Pulsed Discharge, Lead-Acid Batteries II. Modeling. J. Electrochem. Soc. 1990, 137, 3701-3707. [CrossRef] 
18. Sahapatsombut, U.; Cheng, H.; Scott, K. Modelling the micro-macro homogeneous cycling behaviour of a lithium-air battery. J. Power Sources 2013, 227, 243-253. [CrossRef]

19. Wang, C.; Creuziger, A.; Stafford, G.; Hussey, C.L. Anodic Dissolution of Aluminum in the Aluminum Chloride-1-Ethyl-3-methylimidazolium Chloride Ionic Liquid. J. Electrochem. Soc. 2016, 163, H1186-H1194. [CrossRef]

20. Zheng, Y.; Zheng, Y.; Wang, Q.; Wang, Z.; Tian, D. Density and Viscosity of Binary Mixtures of 1-Ethyl-3-methylimidazolium Heptachlorodialuminate and Tetrachloroaluminate Ionic Liquids. J. Chem. Eng. Data 2017, 62, 4006-4014. [CrossRef]

21. Tasaki, K.; Goldberg, A.; Lian, J.J.; Walker, M.; Timmons, A.; Harris, S.J. Solubility of lithium salts formed on the lithium-ion battery negative electrode surface in organic solvents. J. Electrochem. Soc. 2009, 156, A1019-A1027. [CrossRef]

22. Andrei, P.; Zheng, J.P.; Hendrickson, M.; Plichta, E.J. Some Possible Approaches for Improving the Energy Density of Li-Air Batteries. J. Electrochem. Soc. 2010, 157, A1287-A1295. [CrossRef]

23. Stewart, S.G.; Newman, J. The Use of UV/vis Absorption to Measure Diffusion Coefficients in LiPF6 Electrolytic Solutions. J. Electrochem. Soc. 2008, 155, F13-F16. [CrossRef]

24. Read, J.; Mutolo, K.; Ervin, M.; Behl, W.; Wolfenstine, J.; Driedger, A.; Foster, D. Oxygen Transport Properties of Organic Electrolytes and Performance of Lithium/Oxygen Battery. J. Electrochem. Soc. 2003, 150, A1351-A1356. [CrossRef]

25. Nyman, A.; Behm, M.; Lindbergh, G. Electrochemical characterisation and modelling of the mass transport phenomena in LiPF6-EC-EMC electrolyte. Electrochim. Acta 2008, 53, 6356-6365. [CrossRef]

26. Zhang, J.G.; Wang, D.; Xu, W.; Xiao, J.; Williford, R.E. Ambient operation of Li/Air batteries. J. Power Sources 2010, 195, 4332-4337. [CrossRef]

27. Atkins, P.W.; De Paula, J.; Keeler, J. Atkins' Physical chemistry, 11th ed.; Oxford University Press: Oxford, UK; New York, NY, USA, 2018; ISBN 978-0-19-876986-6.

28. Li, Q.; Sun, H.Y.; Takeda, Y.; Imanishi, N.; Yang, J.; Yamamoo, O. Interface properties between a lithium metal electrode and a poly(ethylene oxide) based composite polymer electrolyte. J. Power Sources 2001, 94, 201-205. [CrossRef]

29. Cheng, H.; Scott, K. Carbon-supported manganese oxide nanocatalysts for rechargeable lithium-air Batteries. J. Power Sources 2010, 195, 1370-1374. [CrossRef]

30. Lu, Y.-C.; Kwabi, D.G.; Yao, K.P.C.; Harding, J.R.; Zhou, J.; Zuin, L.; Shao-Horn, Y. Lithium-oxygen batteries: Bridging mechanistic understanding and battery performance. Energy Enironmental Sci. 2011, 4, $2999-3007$. [CrossRef]

31. Lide, D.R. CRC Handbook of Chemistry and Physics, 87th ed.; Taylor \& Francis: Boca Raton, FL, USA, 2007.

32. Kowsari, M.H.; Alavi, S.; Ashrafizaadeh, M.; Najafi, B. Molecular dynamics simulation of imidazolium-based ionic liquids. I. Dynamics and diffusion coefficient. J. Chem. Phys. 2008, 129, 224508. [CrossRef]

33. Bogolowski, N.; Drillet, J.-F. Activity of different AlCl3-based electrolytes for the electrically rechargeable aluminium-air battery. Electrochim. Acta 2018, 274, 353-358. [CrossRef]

34. Nagayama, M.; Tamura, K. Dissolution of the anodic oxide film on aluminium in a sulphuric acid solution. Electrochim. Acta 1967, 12, 1097-1107. [CrossRef]

35. Sato, N. A theory for breakdown of anodic oxide films on metals. Electrochim. Acta 1971, 16, $1683-1692$. [CrossRef]

36. Chao, C.Y.; Lin, L.F.; Macdonald, D.D. A Point Defect Model for Anodic Passive Films I. Film Growth Kinetics. J. Electrochem. Soc. 1981, 128, 1187-1194. [CrossRef]

37. Lin, L.F.; Chao, C.Y.; Macdonald, D.D. A Point Defect Model for Anodic Passive Films II. Chemical Breakdown and Pit Initiation. J. Electrochem. Soc. 1981, 128, 1194-1198. [CrossRef]

38. Macdonald, D.D. The Point Defect Model for the Passive State. J. Electrochem. Soc. 1992, 139, 3434-3449. [CrossRef]

39. Bard, A.J.; Faulkner, L.R. Electrochemical Methods: Fundamentals and Applications, 2nd ed.; Wiley: New York, NY, USA, 2001; ISBN 978-0-471-04372-0. 
40. Gu, W.B.; Wang, C.Y.; Liaw, B.Y. Micro-Macroscopic Coupled Modeling of Batteries and Fuel Cells II. Application to Nickel-Cadmium and Nickel-Metal Hydride Cells. J. Electrochem. Soc. 1998, 145, 3418-3427. [CrossRef]

41. Newman, J.S.; Thomas-Alyea, K.E. Electrochemical Systems, 3rd ed.; J. Wiley: Hoboken, NJ, USA, 2004; ISBN 978-0-471-47756-3. article distributed under the terms and conditions of the Creative Commons Attribution (CC BY) license (http://creativecommons.org/licenses/by/4.0/). 